\title{
Identification of potential phytochemical inhibitors as promising therapeutics against SARS-CoV-2 and molecular dynamics simulation
}

\author{
Anik Banik¹, Emran Hossain Sajib', Anamika Deb', Sheikh Rashel Ahmed ${ }^{1,2}$, Md- Tariqul \\ Islam $^{3 *}$, Soykot Roy ${ }^{4}$, Shiuly Sinha ${ }^{1}$, Hlamrasong Marma ${ }^{1}$, Kazi Faizul Azim ${ }^{1,5,6}$
}

${ }^{1}$ Faculty of Biotechnology and Genetic Engineering, Sylhet Agricultural University, Sylhet-3100, Bangladesh

${ }^{2}$ Department of Plant and Environmental Biotechnology, Sylhet Agricultural University, Sylhet3100, Bangladesh.

${ }^{3}$ Department of Microbiology and Immunology, Sylhet Agricultural University, Sylhet, 3100, Bangladesh.

${ }^{4}$ Department of Biosciences, University of Hertfordshire, Hatfield, Hertfordshire AL10 9AB, UK ${ }^{5}$ Department of Microbial Biotechnology, Sylhet Agricultural University, Sylhet, 3100, Bangladesh.

${ }^{6}$ Faculty of Pharmacy, Universite de Tours, Tours 37200, France.

*Corresponding Author at: Department of Microbiology and Immunology, Sylhet Agricultural University, Sylhet, 3100, Bangladesh.

\section{Md- Tariqul Islam}

E-mail: tariqul.mi@sau.ac.bd

Phone: $+\mathbf{8 8 0 1 8 1 5 8 6 0 3 6 8}$ 


\begin{abstract}
The high infectivity and mortality of novel coronavirus has caused a serious concern all over the world. Still, there is no specific drug or preventive medication to treat SARS-CoV-2 infection despite comprehensive analysis by the researchers. This study was designed to demonstrate the efficacy of some phyto-chemical compounds against SARS-CoV-2 by using both structure and ligand based virtual screening methods. A total of 33 plant metabolites were screened against SARS-CoV-2 main protease proteins (MPP), Nsp9 RNA binding protein, spike receptor binding domain and HR2 domain using a molecular docking approach. Results showed that three metabolites, i.e., Limonin, Isoflavone, and Coumadin conferred maximum binding affinity with all key proteins of SARS-CoV-2. For each viral protein, the critical binding sites and drug surface hotspots have been unraveled. ADME analysis indicated that none of the compounds have adverse effects that could decrease their drug-like properties. Moreover, toxicity pattern analysis also unmasked the non-toxic nature of the top drug candidates. The RMSD values of top ligandmacromolecule complexes were less than $2 \AA$, while RMSF values showed regular atomic fluctuations in the molecular dynamics study. Notably, most of the target class by top drug candidates belonged to enzyme groups (e.g. oxidoreductases, protease, Kinase). Results of drug similarity prediction revealed two approved structural analogs of Coumadin named Warfarin (DB00682) and Phenprocoumon (DB00946) from DrugBank. In addition, Isoformononetin an experimental drug analog of isoflavone could also be an option for the treatment of viral infections. For limonin there was no analog found in drugbank. The study can pave the way for the creation of effective SARS-CoV-2 medications and preventive measures. We highly recommend further in vivo trials for the experimental validation of our findings
\end{abstract}

Keywords: SARS-CoV-2, Phyto-chemicals, Docking, Molecular Dynamics, ADME analysis

\title{
Conflict of interest
}

The authors declare that they have no conflict of interests. 


\section{Introduction}

The abrupt outbreak of 2019 novel coronavirus which was originated from Wuhan, China, indicated as the third introduction of a virulent coronavirus into the human society. It not only affects the healthcare system, but also shatters the global economy in twinkling of an eye. The novel coronavirus found at the end of 2019 was named as 2019 novel coronavirus or "2019-nCoV" by the World Health Organization (WHO) and latterly this institution named it as SARS-CoV-2 (severe acute respiratory syndrome coronavirus 2) (Zhu et al., 2020; Chen et al., 2020). The disease or illness caused by (SARS-CoV-2) is known as COVID 19 and it has become one of the leading cause of death in some areas of the world (Wolf et al., 2020; Magnani et al., 2020). According to the report of WHO, as of October 6, 2020, a total of 35,274,993 confirmed cases of COVID-19 and a total of 1,038,534 deaths were recorded and its infection rate is rising at a drastic rate that could exert a worldwide threat to mankind (Zhou et al., 2020a). The fatality rate of SARS-CoV-2 $(5.4 \%)$ is calculated by WHO, which is less than previous lethal diseases SARS and MERS that had death rates of $9.6 \% \& 35 \%$ respectively (Guo et al., 2020).

SARS-CoV, MERS-CoV, and SARS-CoV-2 belong to a family known as Coronaviridae. This family of viruses possesses a genome of about 27-32 kb which is a large single-stranded and positive-sense RNA genome (Pyrc et al., 2006). Their genomes generally contain a 50methylguanosine cap at the beginning, a 30-poly-A tail at the end, and a total of 6-10 genes in between. Their genes order is usually greatly conserved, where the first one being replication- and transcription-related, and the rest, structural (DeWit et al.; 2016). There is evidence that SARSCoV-2 has more sequence similarity with SARS-CoV than MERS CoV, ensuring SARS-CoV as its close relative (Chan et al., 2020). The virus infects human via same entry point of ACE receptor, then releasing in respiratory tract (Hoffmann et al., 2020; Wan et al., 2020).

The structural proteins of SARS-CoV-2 include the spike (S), envelope (E), and membrane (M) that construct the viral coat, and the nucleocapsid $(\mathrm{N})$ protein. These usually translate from the subgenomic RNAs. Some of these proteins convert later into glycoproteins through glycosylation process in the Golgi apparatus. Among all these proteins, the spike (S) glycoprotein is the most significant potential therapeutic target, as it is responsible for the attachment of the virus to the 
host cells. S protein is primed by the host cell protease and it is recognized by the cellular receptor (Hoffmann et al., 2020).

SARS-CoV-2 is responsible for causing severe human respiratory syndrome (Velavan and Meyer, 2020). The virus mainly spread by means of community transmission, while SARS and MERS affected healthy peoples through nosocomial spread (Munster et al., 2020). Fever (83-98\%), cough (59-82\%), breath shortness (19-55\%), and muscle ache (11-44\%) are the common symptoms of COVID-19, which are alike to those of SARS and MERS. A few days before the onset of fever, some patients may have sore throat, rhinorrhea, headache and confusion, suggesting that fever is a vital symptom (Haung et al. , 2020). Recently it has been reported that COVID-19 patients may have another severe condition and it is lymphopenia which means lower white blood cell counts (Chan et al., 2020).

Till now, there is no specific, safe and effective drug or vaccine for the treatment of human coronavirus. Therefore, CoVs are considered to be a kind of viruses which can pose a huge threat to human being. A few drug candidates have been found to be effective in vitro studies. But it is not possible to perform clinical trials of new drugs within shorter period of time (Dhama et al., 2020). As the condition of epidemic situation is getting worsen day by day, medicinal plants may be alternative to be used in making drugs as early as possible. From ancient times, different types of medical plants are very popular to treat diseases because of their effective medicinal value (Suheda et al., 2015). Again different parts of these medicinal plants contain numerous phytochemicals which are being used for the remedial purposes of health deteriorating diseases (Kumar et al., 2020). On the other hand, chemical based therapies sometimes show various limitations such as drug-resistance, severe side effects, adverse toxicity profiles and so on (Suheda et al., 2015). For this reason, this study aimed to find out some potential plant metabolites through virtual screening methods and various computational investigations which can be used as effective drug candidates against the infection of SARS-CoV-2. 


\section{Materials and Methods}

\subsection{SARS-CoV-2 proteins/protein-domains and plant metabolites retrieval}

The RCSB Protein Data Bank was utilized for the retrieval of 3D structures of SARS-Cov2 main proteases (6W63), Nsp9 (Non-structural protein-9) RNA binding protein (6W4B), Spike receptor binding domain (6M0J) and HR2 Domain (6LVN) (Rose et al., 2017). A complete of 33 plant based bioactive chemical compound under several classes were extracted in SDS (3D) format from the renowned PubChem database (https://pubchem.ncbi.nlm.nih.gov/)(Kim et al., 2016) (Table 1). Later on, the SDS structures were converted into PDB format by means of OpenBabel v2.3 software (O'Boyle et al., 2011).

Table 1: List of plant metabolites with respective source and activities.

\begin{tabular}{|c|c|c|c|c|c|}
\hline Metabolites & $\begin{array}{l}\text { Pubchem } \\
\text { CID }\end{array}$ & Chemical Class & Plant Source & Activities & References \\
\hline $\begin{array}{l}\text { Allyl propyl } \\
\text { disulfide }\end{array}$ & 16591 & $\begin{array}{l}\text { Allyl sulfur } \\
\text { compounds }\end{array}$ & Allium cepa Linn & $\begin{array}{l}\text { Prevents irregular heart beat and } \\
\text { abnormal blood pressure. It also prevents } \\
\text { cancers, coronary heart disease, } \\
\text { arteriosclerosis (hardening of the } \\
\text { arteries), bronchitis, dry or stubborn } \\
\text { cough and blood clots. }\end{array}$ & $\begin{array}{l}\text { Ozougwu and } \\
\text { Eyo } \\
(2011)\end{array}$ \\
\hline Apigenin & 5280443 & Flavonoids & $\begin{array}{l}\text { Passiflora foetida } \\
\mathrm{L}\end{array}$ & $\begin{array}{l}\text { Antispasmodic, antibacterial, } \\
\text { antihypertension, antiproliferative activity } \\
\text { on human breast } \\
\text { adenocarcinoma }\end{array}$ & $\begin{array}{l}\text { Salehi et al., } \\
\text { (2019) }\end{array}$ \\
\hline $\begin{array}{l}\text { Aristolochic } \\
\text { acid }\end{array}$ & 2236 & $\begin{array}{l}\text { Monocarboxylic } \\
\text { acid }\end{array}$ & $\begin{array}{l}\text { Aristolochia albida } \\
\text { Duchartre }\end{array}$ & Anthelmintic, anti-inflammatory & $\begin{array}{l}\text { Okujagu et al., } \\
\text { (2008) }\end{array}$ \\
\hline Artocarpesin & 399491 & $\begin{array}{l}\text { 6-prenylated } \\
\text { flavones }\end{array}$ & $\begin{array}{l}\text { Artocarpus } \\
\text { heterophyllus Lam }\end{array}$ & Anti-ulcer & $\begin{array}{l}\text { Lawal et al, } \\
2010\end{array}$ \\
\hline Ascorbic acid & 54670067 & Dihydrofurans & Citrus aurantifolia & Anti-malaria & $\begin{array}{l}\text { Odugbemi } \\
(2006)\end{array}$ \\
\hline
\end{tabular}




\begin{tabular}{|c|c|c|c|c|c|}
\hline Asparagine & 6267 & $\begin{array}{l}\text { Carboxylic acids } \\
\text { and derivatives }\end{array}$ & Citrus aurantifolia & Anti-malaria & $\begin{array}{l}\text { Odugbemi } \\
(2006)\end{array}$ \\
\hline Camphene & 6616 & Prenol lipids & $\begin{array}{l}\text { Cymbopogon } \\
\text { citrates }\end{array}$ & Anti-malaria & $\begin{array}{l}\text { Odugbemi } \\
(2006)\end{array}$ \\
\hline Chavicine & 1548912 & Alkaloids & Piper nigrum $\mathrm{L}$. & $\begin{array}{l}\text { It inhibits pro-inflammatorycytokines that } \\
\text { are produced by tumour cells (anti- } \\
\text { tumourigenic). It is also immune } \\
\text { stimmulatory, } \\
\text { stomachic,carminative, anticholestrolemic } \\
\text { and anti-oxidant. It also inhibits the } \\
\text { growth of malaria parasite. }\end{array}$ & $\begin{array}{l}\text { Shaba et al. } \\
(2012)\end{array}$ \\
\hline Chrysoeriol & 5280666 & Flavonoids & $\begin{array}{l}\text { Passiflora foetida } \\
\text { L }\end{array}$ & $\begin{array}{l}\text { Antispasmodic, antibacterial, } \\
\text { antihypertension, antiproliferative } \\
\text { activity on human breast } \\
\text { adenocarcinoma }\end{array}$ & $\begin{array}{l}\text { Moongkarndi } \\
\text { et al., } \\
\text { (2004) }\end{array}$ \\
\hline Cianidanol & 9064 & Flavonoids & $\begin{array}{l}\text { Ocimum } \\
\text { gratissimum } \mathrm{L}\end{array}$ & $\begin{array}{l}\text { It prevents breast cancer and fat } \\
\text { accumulation. It inhibits growth of } \\
\text { disease } \\
\text { microorganisms(antimicrobial). It has } \\
\text { antioxidant activity and also preventing } \\
\text { the formation of oxidized Low-density } \\
\text { Lipoprotein (LDL), which is considered } \\
\text { to induce cardiovascular } \\
\text { disease. }\end{array}$ & $\begin{array}{l}\text { Obho (2006) } \\
\text { Amic et } \\
\text { al., (2003); } \\
\text { Nwinyi et. } \\
\text { al. (2009); }\end{array}$ \\
\hline Citronellal & 7794 & Prenol lipids & $\begin{array}{l}\text { Cymbopogon } \\
\text { citrates }\end{array}$ & Anti-malaria & $\begin{array}{l}\text { Odugbemi } \\
(2006)\end{array}$ \\
\hline Cleomiscosin B & 156875 & Coumarinolignoid & Cleome viscose $L$. & Antiscorbutic,anthelmintic & $\begin{array}{l}\text { Okujagu et al., } \\
\text { (2008) }\end{array}$ \\
\hline Coumadin & 54678486 & $\begin{array}{l}\text { Coumarins and } \\
\text { derivatives }\end{array}$ & Sida acuta Burm. F & $\begin{array}{l}\text { Antipyretic and has inhibitory activity } \\
\text { against disease causing bacteria }\end{array}$ & $\begin{array}{l}\text { Iroha et al } \\
(2009)\end{array}$ \\
\hline Dihydromorin & 5458714 & Flavanonols & $\begin{array}{l}\text { Artocarpus } \\
\text { heterophyllus Lam }\end{array}$ & Anti-ulcer & $\begin{array}{l}\text { Lawal et al, } \\
(2010)\end{array}$ \\
\hline
\end{tabular}




\begin{tabular}{|c|c|c|c|c|c|}
\hline Flavylium & 145858 & Flavonoids & $\begin{array}{l}\text { Mallotus } \\
\text { oppositifolius } \\
\text { (Geisel) mull. Arg. }\end{array}$ & Anti-malarial and inhibits fungal growth. & $\begin{array}{l}\text { Farombi et al., } \\
\text { (2001) }\end{array}$ \\
\hline Genkwanin & 5281617 & Flavonoids & Alnus glutinosa & $\begin{array}{l}\text { Anti-inflammatory, anti-bacterial, } \\
\text { antiplasmodial and radical scavenging } \\
\text { activities. }\end{array}$ & $\begin{array}{l}\text { O'Rourke et } \\
\text { al., } \\
(2005)\end{array}$ \\
\hline Geraniol & 637566 & Prenol lipids & $\begin{array}{l}\text { Cymbopogon } \\
\text { citrates }\end{array}$ & Anti-malaria & $\begin{array}{l}\text { Odugbemi } \\
(2006)\end{array}$ \\
\hline Gingerol & 442793 & Phenols & $\begin{array}{l}\text { Zingiber officinale } \\
\text { Roscoe }\end{array}$ & $\begin{array}{l}\text { It prevents chilblains and circulatory } \\
\text { problems such as Raynaud's disease. It is } \\
\text { highly antiseptic, activating } \\
\text { immunity and dispelling a whole variety } \\
\text { of bacterial and viral infections. It also } \\
\text { inhibits blood clotting. }\end{array}$ & $\begin{array}{l}\text { Ozougwu and } \\
\text { Eyo } \\
(2011)\end{array}$ \\
\hline $\begin{array}{l}\text { Hydrocyanic } \\
\text { acid }\end{array}$ & 768 & $\begin{array}{l}\text { Organonitrogen } \\
\text { compounds }\end{array}$ & $\begin{array}{l}\text { Crytolopsis } \\
\text { sanguinolenta }(\text { lindl })\end{array}$ & Anti-tumor, anti-inflammatory & $\begin{array}{l}\text { Prabu et al. } \\
(2006)\end{array}$ \\
\hline Isoflavone & 72304 & Isoflavonoids & $\begin{array}{l}\text { Ocimum } \\
\text { gratissimum } \mathrm{L}\end{array}$ & $\begin{array}{l}\text { It prevents breast cancer and fat } \\
\text { accumulation. It inhibits growth of } \\
\text { disease causative microorganisms } \\
\text { (antimicrobial). It has antioxidant activity } \\
\text { and also preventing the formation of } \\
\text { oxidized Low-density Lipoprotein (LDL), } \\
\text { which is } \\
\text { considered to induce cardiovascular } \\
\text { disease. }\end{array}$ & $\begin{array}{l}\text { Obho (2006) } \\
\text { Amic et } \\
\text { al., (2003); } \\
\text { Nwinyi et. } \\
\text { al. (2009); }\end{array}$ \\
\hline
\end{tabular}




\begin{tabular}{|c|c|c|c|c|c|}
\hline Limonin & 179651 & Prenol lipids & $\begin{array}{l}\text { Cymbopogon } \\
\text { citrates }\end{array}$ & Anti-malaria & $\begin{array}{l}\text { Odugbemi } \\
(2006)\end{array}$ \\
\hline Myrcene & 31253 & Prenol lipids & Piper nigrum $\mathrm{L}$. & $\begin{array}{l}\text { It inhibits pro-inflammatorycytokines that } \\
\text { are produced by tumour cells (anti- } \\
\text { tumourigenic). It is also immune } \\
\text { stimmulatory, } \\
\text { stomachic,carminative, anticholestrolemic } \\
\text { and anti-oxidant. It also inhibits the } \\
\text { growth of malaria parasite. }\end{array}$ & $\begin{array}{l}\text { Shaba et al. } \\
\text { (2012) }\end{array}$ \\
\hline Norartocarpetin & 5481970 & Flavonoids & $\begin{array}{l}\text { Artocarpus } \\
\text { heterophyllus Lam }\end{array}$ & Anti-ulcer & $\begin{array}{l}\text { Lawal et al, } \\
(2010)\end{array}$ \\
\hline Paucine & 5280559 & Phenols & $\begin{array}{l}\text { Pentacletha } \\
\text { macrophylla Benth }\end{array}$ & Anticarcinogenic & $\begin{array}{l}\text { Onwukaeme } \\
\text { (1993) }\end{array}$ \\
\hline Procyanidin & 107876 & Flavonoids & $\begin{array}{l}\text { Adansonia digitata } \\
\text { L. }\end{array}$ & Anti- inflammation & $\begin{array}{l}\text { Zhao et al., } \\
\text { (1999) }\end{array}$ \\
\hline Quinine & 3034034 & $\begin{array}{l}\text { Cinchona } \\
\text { alkaloids }\end{array}$ & $\begin{array}{l}\text { Azadirachta indica } \\
\text { A.Juss. }\end{array}$ & Anti malaria, insecticide & $\begin{array}{l}\text { Lawal et al, } \\
2010\end{array}$ \\
\hline Reserpine & 5770 & $\begin{array}{l}\text { Yohimbine } \\
\text { alkaloids }\end{array}$ & $\begin{array}{l}\text { Rauwolfia } \\
\text { vomitoriaAfz } \\
\text { Or } R \text {. Serpentine } \\
\text { (L.) Benth ex. Kurz }\end{array}$ & Antihypertensive & $\begin{array}{l}\text { Kokwaro, } \\
(1993) ; \\
\text { Sofowora } \\
(2008)\end{array}$ \\
\hline Riboflavin & 493570 & $\begin{array}{l}\text { Pteridines and } \\
\text { derivatives }\end{array}$ & $\begin{array}{l}\text { Moringa oleifera } \\
\text { Lam. }\end{array}$ & Antioxidants, antimicrobial & $\begin{array}{l}\text { Odugbemi } \\
(2006)\end{array}$ \\
\hline Steppogenin & 21596130 & Flavonoids & $\begin{array}{l}\text { Artocarpus } \\
\text { heterophyllus Lam }\end{array}$ & Anti-ulcer & $\begin{array}{l}\text { Lawal et al, } \\
2010\end{array}$ \\
\hline
\end{tabular}




\begin{tabular}{|l|l|l|l|l|l|}
\hline Stigmasterol & 5280794 & $\begin{array}{l}\text { Steroids and } \\
\text { steroid derivatives }\end{array}$ & $\begin{array}{l}\text { Amaranthus } \\
\text { spinosus L }\end{array}$ & Antipyretic & $\begin{array}{l}\text { Okujagu et al., } \\
(2008)\end{array}$ \\
\hline Triterpenoid & 71597391 & Prenol lipids & Sida acuta Burm. F & $\begin{array}{l}\text { Antipyretic and has inhibitory activity } \\
\text { against disease causing bacteria }\end{array}$ & $\begin{array}{l}\text { Iroha et al., } \\
(2009)\end{array}$ \\
\hline Vanillin & 1183 & Phenols & $\begin{array}{l}\text { Antimicrobial anilla planifolia } \\
\text { activities, Antioxidant and antimutagenic } \\
\text { properties. }\end{array}$ & $\begin{array}{l}\text { Mourtzinos et } \\
\text { al., (2009); } \\
\text { Kim et } \\
\text { (2014) }\end{array}$ \\
\hline Yohimbine & 8969 & $\begin{array}{l}\text { Yohimbine } \\
\text { alkaloids }\end{array}$ & $\begin{array}{l}\text { Rauwolfia } \\
\text { vomitoriaAfz } \\
\text { Or R. Serpentine } \\
\text { (L.) Benth ex. Kurz }\end{array}$ & $\begin{array}{l}\text { Antihypertensive } \\
\text { Kokwaro, } \\
(1993) ; \\
\text { Sofowora } \\
(2008)\end{array}$ \\
\hline
\end{tabular}

\subsection{Screening of plant metabolites against SARS-CoV-2 proteins/protein-domains}

Molecular docking facilitates the identification of therapeutically potential compounds against particular drug targets of lethal microorganisms (Pinzi L and Rastelli G, 2019). It is a key tool in computer-assisted drug design and structural molecular biology that is effective to model the interaction between a small molecule and a protein (Meng et al., 2011). The PatchDock server was employed to estimate the binding affinity of 33 plant metabolites with selected SARS-CoV-2 proteins/protein domains (drug targets/macromolecules) (Schneidman-Duhovny et al., 2005; Azim et al., 2020; Banik et al., 2020). A recent experimental study pointed out alpha-ketoamide (CID 6482451) as an inhibitor of SARS-CoV-2 main protease protein (Zhang et al., 2020). For this reason, the present study used it as positive control and also conducted to docking analysis against all four proteins/protein domains. The formed docked complexes were then refined by FireDock refinement tool (Mashiach et al., 2008). Visualization of the ligand binding 
complexes wasperformed by Discovery Studio v3.1 (Wang et al., 2015) and PyMOL v2.0 (DeLano, 2002).

\subsection{Analysis of drug surface hotspot and ligand binding pocket prediction}

The drug surface hotspot of SARS-CoV-2 proteins was analysed by investigating the docked complexes with the top metabolites using LigPlot+, Discovery Studio and PyMOL v.2.0 software (Wang et al., 2015; Delano 2002; Banik et al., 2020). Binding patterns of Limolin, avicularin, Isoflavone, and Coumadin with four macromolecules were allowed for comparative structural analysis. Moreover, interaction of Alpha-ketoamide with the studied proteins were also investigated.

\subsection{Free energy calculation and Molecular Dynamics Study}

Ligand-protein complex binding interaction feature analysis focused on traditional molecular dynamics were carried out by utilizing the Ligand and Receptor Molecular Dynamics (LARMD) server (http://chemyang.ccnu.edu.cn/ccb/server/LARMD) (Yang et al., 2019). The free binding energy $\left(\Delta G_{b i n d}\right)$ was estimated on the basis of binding energy $\left(\Delta E_{b i n d}\right)$, conformational entropy ($\left.T \Delta S_{\text {conf }}\right)$ and solvation entropy $\left(T \Delta S_{\text {sol }}\right)$ (Raha \& Merz, 2005). The MM/GBSA method and empirical method was utilized to calculate enthalpy and the entropy, respectively (Hou et al., 2011; Hao et al., 2009 and Pan et al., 2008).

$$
\Delta G_{\text {bind }}=\Delta E_{\text {bind }}-T \Delta S_{\text {sol }}-T \Delta S_{\text {conf }} \text {. }
$$

Molecular dynamics (MD) simulation was performed in order to analyze the docked poses. In this study, MD simulation was performed for the top bioactive drug candidates for each targeted protein.

The conformational stability of the ligand-protein complex interactions was evaluated using the study of molecular dynamics simulations by performing normal mode analysis (NMA) via iMODS server (http:/imods.chaconlab.org) predicting various properties such as deformability, mobility profiles, eigen-values (López-Blanco et al., 2014). LARMD tools was adopted to run simulation with water explicites and the time intervalwas set to $4 \mathrm{~ns}$. AMBER16 was used as the force field in this MD simulation where the Sander module was used to perform the minimization in 4 steps before the simulation (Case et al., 2005). The 2000 steps steepest descent method along with the 3000 steps conjugated gradient methodwere used in all minimization processes and the system was 
heatedfrom 10 to $300 \mathrm{~K}$ in 30 ps. Further the complexes, the root mean square deviation (RMSD) and gyration radius ( $\mathrm{Rg}$ )along the root mean square fluctuations were measured and analyzed using LARMD server (Yang et al., 2019). This server uses AMBER16 program from the trajectory with a time interval per pico-second (Roe \& Cheatham, 2013). Finally, periodic boundary condition was applied to relax all the atoms in $300 \mathrm{~K}$ (Yang, et al., 2019).

\subsection{Drug profile analysis of top metabolites}

Absorption, distribution, metabolism and excretion (ADME) are the four important processes that describe the deposition of a drug within an organism (Vugmeysteret al., 2012). Proper pharmacological activity (potency and selectivity) and good ADME properties are the criteria of an ideal drug candidate (Lin et al., 2003). The absorption, distribution, metabolism and excretion properties of the chosen top metabolites were determined by using SwissADME server (Daina et al., 2017). The BOILED-Egg model was utilized to evaluate the Blood-brain barrier (BBB) in the top metabolites(Daina and Zoete, 2016). Furthermore, the relative toxicity of top drug candidates was assessed via pkCSM online tool. This effective server predict pharmacokinetic properties relying on graph-based signatures that describe distance patterns between atoms (Pires et al., 2015; Rahman et al., 2020). Examining carcinogenicity of these candidates was also conducted by using admetSAR (Cheng et al., 2012).

\subsection{Prediction of drug targets and available drug molecules from DrugBank}

The probable macromolecular targets of top drug candidates were predicted by employing SwissTargetPrediction server (Daina et al., 2019). It generally estimates on the basis of combination of $2 \mathrm{D}$ and 3D uniformity with a collection of 370000 acquainted bioactive compounds on around 3000 proteins. Besides, the homology screening of predicted top drug candidates was performed via SwissSimilarity web toolsto screen out potential drug molecules against SARS-CoV-2 (Zoete et al., 2016). Approaches such as FP2 fingerprints, spectrophores, electroshape and align-IT are used by this server to detect experimental, approved or commercially available drugs from DrugBank by means ofligand-based virtual screening of various libraries of small molecules (Zoete et al., 2016).

\section{Results}

\subsection{Screening of plant metabolites against SARS-CoV-2}


Extracted structures of SARS-CoV-2 proteins/protein-domains (macromolecules) and plant metabolites (ligands) were optimized and utilized for docking purpose to evaluate the binding affinity between these macromoleculesandligands. Depending on global binding energy the metabolites were ordered. According to the result three top scorers (metabolites) were selected that experienced superior outcomes in case of minimum binding energy with each of the macromolecules (Table 2 and Supplementary File 1). Top three scorers, isoflavone, limonin and coumadin, had the excellent binding interactions with the four macromolecules (Fig. 1 and Table 2). Among them, isoflavone showed the strongest binding affinity with spike receptor binding domain $(-52.98 \mathrm{kcal} / \mathrm{mol})$ and SARS-Cov-2 main protease $(-59.55 \mathrm{kcal} / \mathrm{mol})$, while limonin with HR2 Domain (-28.89 kcal/ mol) and coumadin with Nsp9 (Non-structural protein-9) RNA binding protein $(-45.62 \mathrm{kcal} / \mathrm{mol})$ in terms of highest binding capacity (Fig. 2 and Table 2).

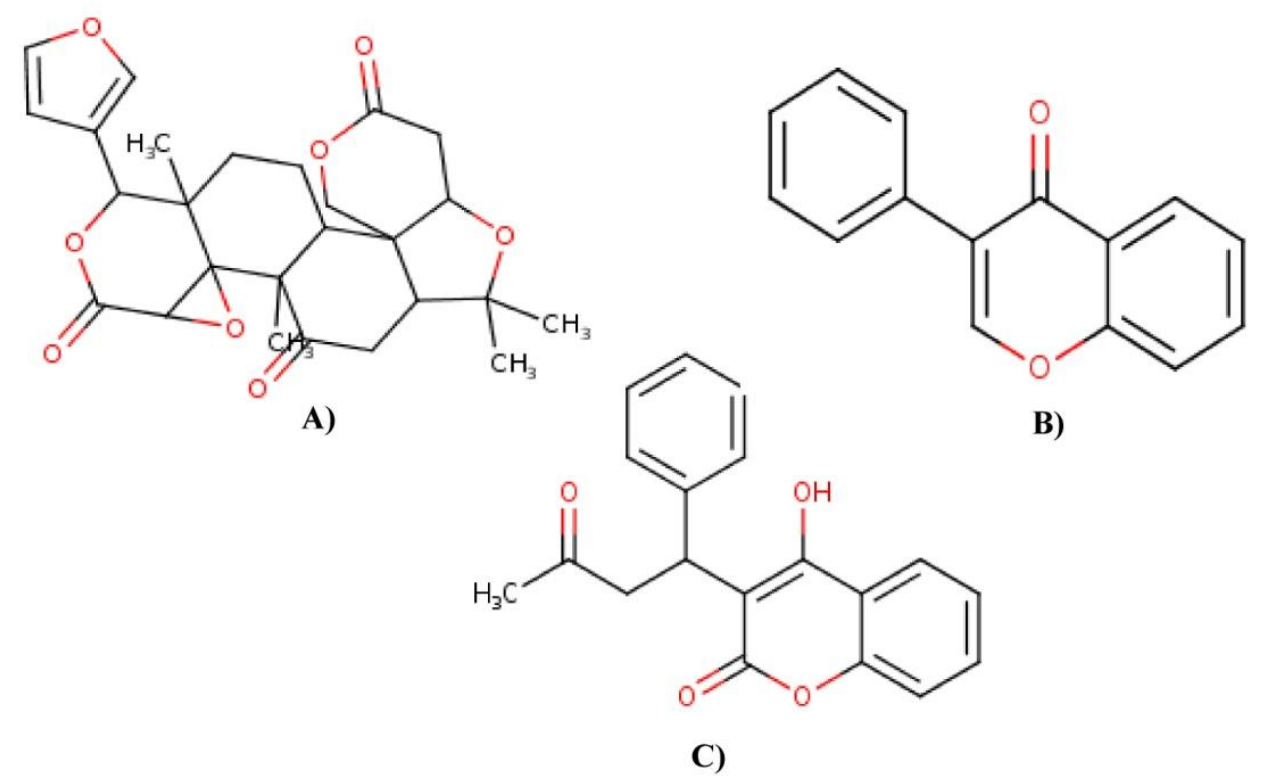

Figure 1: Chemical structures of Limonin (A), Isoflavone (B), Coumadin (C). 


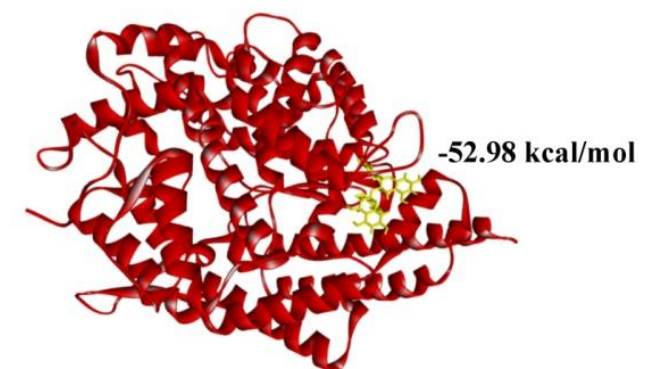

A)

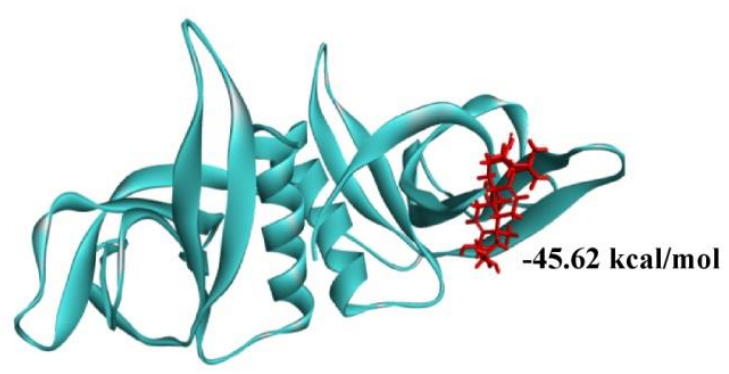

C)

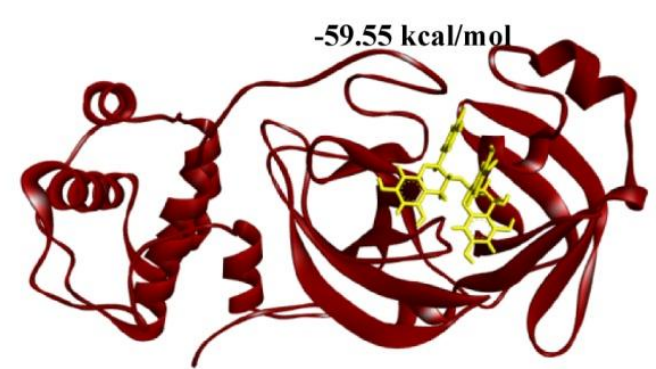

B)

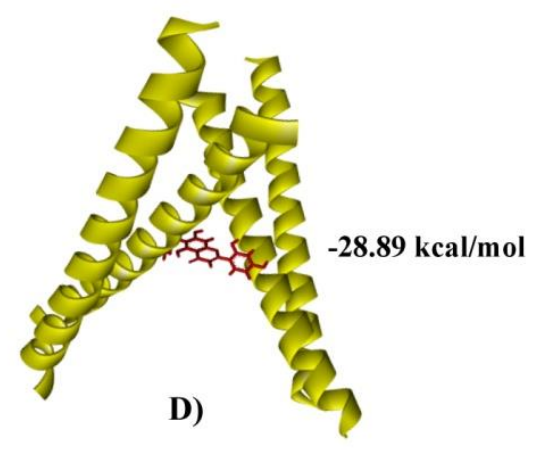

Figure 2: Molecular interaction of Isoflavone with SARS-CoV-2 Spike receptor binding domain (A) and Main protease (B), Nsp9 (Non-structural protein-9) RNA binding protein with Coumadin (C), HR2 Domain with Limonin (D).

Table 2: Docking results and interaction sites of the screened top 3 metabolites.

\begin{tabular}{|l|l|l|l|l|l|l|l|}
\hline \multirow{2}{*}{ Macromolecules } & Ligands & $\begin{array}{l}\text { Global } \\
\text { energy }(\mathrm{kcal} / \mathrm{mol})\end{array}$ & Score & Area & ACE & HB & Binding sites \\
\hline & Isoflavone & -25.73 & 4274 & 554.70 & 1.68 & 0.00 & $\begin{array}{l}\text { Gln13, Asp17, } \\
\text { Arg18, Asn20, } \\
\text { Glu21, Val22, } \\
\text { Lys24 }\end{array}$ \\
\cline { 2 - 8 } & Limonin & -28.89 & 4186 & 471.90 & -0.36 & 0.00 & $\begin{array}{l}\text { Lys14, Arg18, } \\
\text { Glu21, } \\
\text { Lys24,Asp17 }\end{array}$ \\
\cline { 2 - 8 } Domain(6LVN) & Coumadin & -26.38 & 3656 & 413.80 & -0.92 & 0.00 & $\begin{array}{l}\text { Lys14, Asp17, } \\
\text { Arg18, Glu21, } \\
\text { Lys24 }\end{array}$ \\
\cline { 2 - 8 } & $\begin{array}{l}\text { a-ketoamide } \\
\text { (Control) }\end{array}$ & -25.52 & 4318 & 564.20 & -2.71 & 0.00 & $\begin{array}{l}\text { Ile16, Asn20, } \\
\text { Lys24, Asn27, } \\
\text { Glu28 }\end{array}$ \\
\hline $\begin{array}{l}\text { Spike receptor } \\
\text { binding domain } \\
\text { (6M0J) }\end{array}$ & Isoflavone & -52.98 & 6254 & 764.30 & 13.56 & 0.00 & $\begin{array}{l}\text { Leu91, Lys94, } \\
\text { Leu95, Gln98, } \\
\text { Ala99, Tyr196, } \\
\text { Gly205, Asp206, }\end{array}$ \\
\hline
\end{tabular}




\begin{tabular}{|c|c|c|c|c|c|c|c|}
\hline & & & & & & & $\begin{array}{l}\text { Tyr207, Glu208, } \\
\text { Val209, Asn210, } \\
\text { Ala396, Asn397, } \\
\text { Lys562, Glu564, } \\
\text { Pro565, }\end{array}$ \\
\hline & Limonin & -41.87 & 4476 & 590.80 & $\begin{array}{l}-5.42 \\
\end{array}$ & 0.00 & $\begin{array}{l}\text { Asn33, His34, } \\
\text { Glu35, Glu37, } \\
\text { Asp38, Leu39, } \\
\text { Lys353, Arg403, } \\
\text { Glu406, Lys417, } \\
\text { Tyr449, Tyr453, } \\
\text { Gln493, Ser494, } \\
\text { Tyr495, Gly496, } \\
\text { Tyr505 }\end{array}$ \\
\hline & Coumadin & -45.91 & 4968 & 624.50 & $\begin{array}{l}- \\
13.47\end{array}$ & 0.00 & $\begin{array}{l}\text { Leu95, Gln98, } \\
\text { Gln102, Tyr196, } \\
\text { Tyr202, Gly205, } \\
\text { Asp206, Tyr207, } \\
\text { Glu208, Val209, } \\
\text { Asn210, Ala396, } \\
\text { Lys562, Glu564 }\end{array}$ \\
\hline & $\begin{array}{l}\alpha \text {-ketoamide } \\
\text { (Control) }\end{array}$ & -60.50 & 5379 & 655.40 & -9.34 & 0.00 & $\begin{array}{l}\text { Lys94, Tyr196, } \\
\text { Asp206, Glu208, } \\
\text { Val209, Asn210 }\end{array}$ \\
\hline \multirow{4}{*}{$\begin{array}{l}\text { Nsp9 (Non- } \\
\text { structural } \\
\text { protein-9) RNA } \\
\text { binding protein } \\
\text { (6W4B) }\end{array}$} & Isoflavone & -40.96 & 5358 & 748.70 & -7.94 & 0.00 & $\begin{array}{l}\text { Asn-1, Ala0, } \\
\text { Met1, Asn2, } \\
\text { Asn3, Gln50, } \\
\text { Asp51, Leu52, } \\
\text { Lys53, Pro72, } \\
\text { Pro73, Arg75, } \\
\text { Tyr88 }\end{array}$ \\
\hline & Limonin & -42.57 & 4388 & 570.80 & $\begin{array}{l}- \\
10.74\end{array}$ & 0.00 & $\begin{array}{l}\text { Asn-1, Ala0, } \\
\text { Met1, Asn2, } \\
\text { Asn3, Gln50, } \\
\text { Lys53, Pro72, } \\
\text { Pro73, Cys74, } \\
\text { Arg75, Tyr88 }\end{array}$ \\
\hline & Coumadin & -45.62 & 4890 & 581.20 & $-\overline{14.28}$ & 0.00 & $\begin{array}{l}\text { Met13, Arg40, } \\
\text { Phe41, Phe57, } \\
\text { Pro58, Lys59, } \\
\text { Ser60, Asp61, } \\
\text { Ile66, Thr68, } \\
\text { Ile92, Val142 }\end{array}$ \\
\hline & $\begin{array}{l}\alpha \text {-ketoamide } \\
\text { (Control) }\end{array}$ & -48.60 & 4458 & 504.60 & $\begin{array}{l} \\
16.39\end{array}$ & 0.00 & $\begin{array}{l}\text { Phe41, Trp54, } \\
\text { Ile66, Thr68, } \\
\text { Glu69 }\end{array}$ \\
\hline
\end{tabular}




\begin{tabular}{|c|c|c|c|c|c|c|c|}
\hline \multirow{4}{*}{$\begin{array}{l}\text { SARS-Cov-2 } \\
\text { main protease } \\
\text { (6W63) }\end{array}$} & Isoflavone & -59.55 & 5028 & 604.80 & $\begin{array}{l} \\
16.48\end{array}$ & 0.00 & $\begin{array}{l}\text { Thr25, Thr26, } \\
\text { Leu27, His41, } \\
\text { Val42, Ser46, } \\
\text { Met49, Pro52, } \\
\text { Tyr54, Leu141, } \\
\text { Asn142, Gly143, } \\
\text { Ser144, Cys145, } \\
\text { His164, Met165, } \\
\text { Glu166, Leu167, } \\
\text { Asp187, Arg188, } \\
\text { Gln189, }\end{array}$ \\
\hline & Limonin & -49.00 & 4704 & 507.40 & $-\overline{14.86}$ & 0.00 & $\begin{array}{l}\text { Thr25, Leu27, } \\
\text { His41, Cys44, } \\
\text { Thr45, Met49, } \\
\text { Cys145, Met165, } \\
\text { Glu166, Leu167, } \\
\text { Pro168, Val186, } \\
\text { Asp187, Arg188, } \\
\text { Gln189, Thr190, } \\
\text { Ala191, Gln192 }\end{array}$ \\
\hline & Coumadin & -51.96 & 4832 & 603.50 & $-\overline{16.85}$ & 0.00 & $\begin{array}{l}\text { His41, Cys44, } \\
\text { Met49, Tyr54, } \\
\text { Tyr118, Phe140, } \\
\text { Leu141, Asn142, } \\
\text { Gly143, Ser144, } \\
\text { Cys145, His163, } \\
\text { His164, Met165, } \\
\text { Glu166, His172, } \\
\text { Val186, Asp187, } \\
\text { Arg188, Gln189 }\end{array}$ \\
\hline & $\begin{array}{l}\alpha \text {-ketoamide } \\
\text { (Control) }\end{array}$ & -56.92 & 4560 & 526.40 & $\begin{array}{l}- \\
16.84\end{array}$ & 0.00 & $\begin{array}{l}\text { Asp197, Leu272, } \\
\text { Gly275, Leu286, } \\
\text { Leu287, Asp289 }\end{array}$ \\
\hline
\end{tabular}

\subsection{Analysis of drug surface hotspot and ligand binding pocket prediction}

To reveal the drug surface hotspot of studied macromolecules, the structural pattern of the docked complexes was explored. The ligand interacting residues of SARS-CoV-2 proteins were investigated and respective positions of these residues were also disclosed (Fig.3 and Table 2). The results indicated that amino acid positions 13 to 24 of HR2 Domainwere most significant for binding with ligands where Asp17, Arg18, Glu21 and Lys24 were binding sites for each of the three top metabolites. Besides, the regions from 91 to 99 and from 196to 210 were revealed as top surface hotspots for spike receptor binding domain in which Leu95, Gln98,Gly205, Asp206, 
Tyr207, Glu208, Val209 and Asn210were prevalent. The ligands experienced greatest binding affinity for 50-75 positions of Nsp9 (Non-structural protein-9) RNA binding protein, and for 141168 and 186-192 regions of SARS-Cov-2 main protease(6W63).
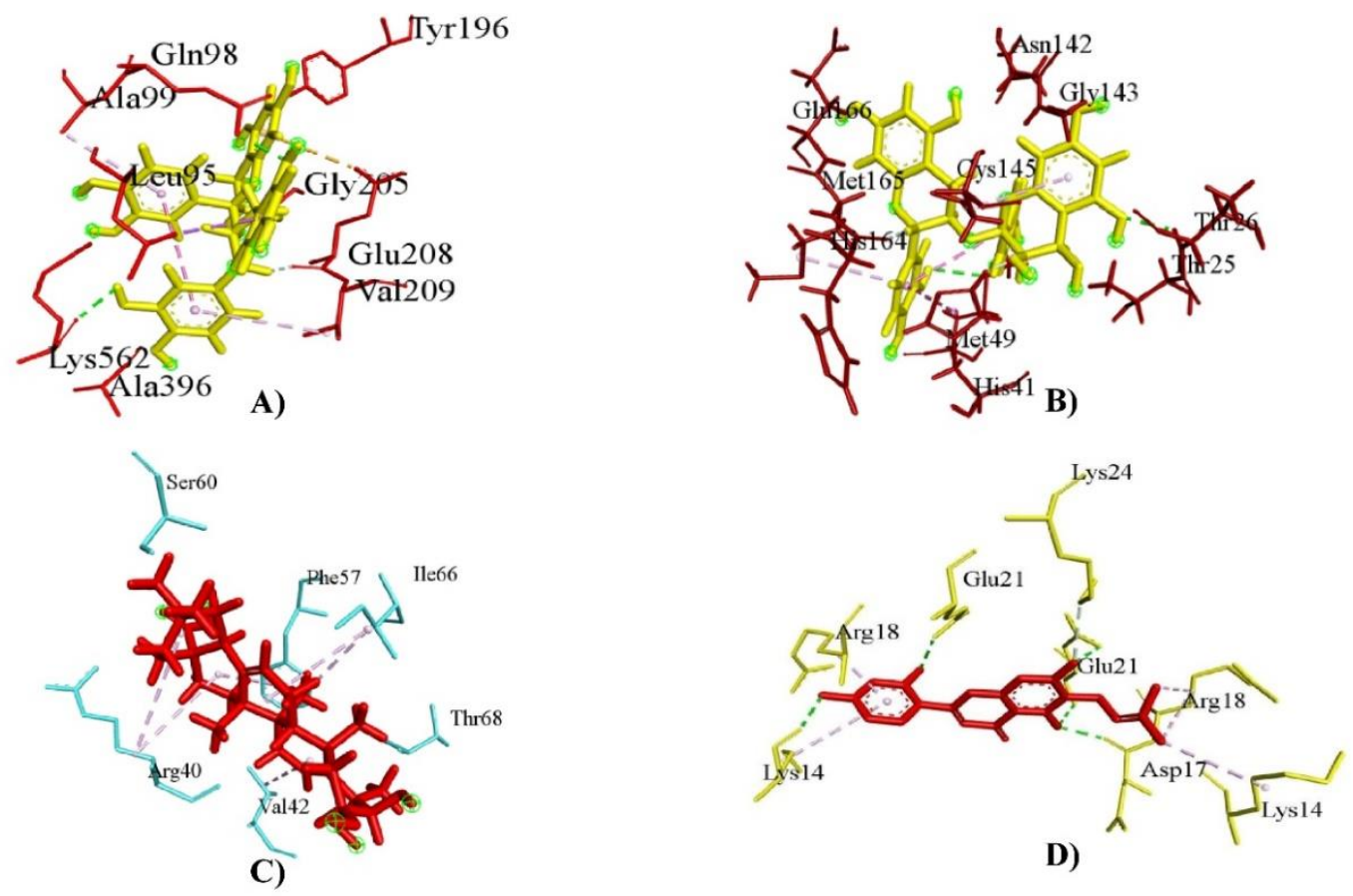

Figure 3: Ligand-Amino acid interaction moede of Isoflavone with SARS-CoV-2 Spike receptor binding domain (A) and Main protease (B), Nsp9 (Non-structural protein-9) RNA binding protein with Coumadin (C), HR2 Domain with Limonin (D).

\subsection{Free energy calculation and Molecular Dynamics Study}

In this study, the estimation of free energies consists of electrostaticenergy (ELE), Van der Waals contribution (VDW), total gas phase en-ergy (GAS) and final estimated binding energy (deltaPB/deltaGB). MM/PB (GB) SA calculations showed that the value of free energy inthe 6W4B in complex with Coumadine, deltaPB $\approx--16.57 \mathrm{kcal} / \mathrm{mol}$. Mean-while, 6W63-Isoflavone complex had the value of deltaPB $\approx-4.72 \mathrm{kcal} / \mathrm{mol}, 6 \mathrm{LVN}$-Limolincomplex had deltaPB $\approx-6.81$ $\mathrm{kcal} / \mathrm{mol}$ and $6 \mathrm{M} 0 \mathrm{~J}-$ Isoflavone complex had the value of deltaPB $\approx-8.04 \mathrm{kcal} / \mathrm{mol}$ (Table 3). The deformability of the structures was mostly dependent on structure hinges. The hinges found in all structure are not significant and found to be stable (Figure 4:A,5:A,6:A,7:A). The B factor analysis showed there was no significant fluctuations means there very less amounts of loops (Figure $4: B, 5: B, 6: B, 7: B)$. The eigen values for the complexes were higher and compact the structure and 
it revealed its resistance to deform. The eigen values $2.243535 \times 10^{-5}$ for 6LVN-Coumadine, $2.707260 \times 10^{-5}$ (Figure 7:C) for 6M0J-isoflavone (Figure 4:C), comparatively higher $1.080318 \mathrm{x}$ $10^{-4}$ for $6 \mathrm{~W} 63$-isoflavone and $2.116669 \times 10^{-4}$ for $6 \mathrm{~W} 4 \mathrm{~B}$-coumadin complex, respectively (Figure 5:C, 6:C). The complex RMSD value for all studied complex was less than $2 \AA$ in Fourstudied complexes (Figure 4:D,5:D,6:D,7:D). The 6W63-Isoflavone complex after 3ns shows a mild fluctuation((Figure 5:D). All the structure didn't show any undesirable repulsion. For all the complexes the RMSF values showed a regular pattern of atomic fluctuations during the molecular dynamics stimulation. The $\mathrm{Rg}$ value were ranging 18.4 to 24.6, The most higher value 24.6 was found in 6M0J-isoflavone complex ((Figure 4:E). While, the SARS-CoV-2 main protease 6W63 complex with isoflavone also showed higher Rg value of 22 (Figure 5:E). The other 6W4Bcoumadin revealed value of 20 and 6LVN-limolin posses19.6 which was lowest (Figure 7:E).

Table 3: Binding free energy $(\mathrm{kcal} / \mathrm{mol})$ of the interaction of the selected bioactive compounds with COVID-19 main protease and other proteins.

\begin{tabular}{|c|c|c|c|c|c|}
\hline \multirow{2}{*}{ Complexes } & \multicolumn{5}{|c|}{ Parameters } \\
\cline { 2 - 6 } & ELE & VDW & GAS & deltaPB & delatGB \\
\hline 6M0J-Isoflavone & -17.53 & -62.64 & -80.17 & -8.04 & -21.60 \\
\hline 6LVN-Limolin & -1.63 & -47.90 & -49.53 & -13.14 & -15.83 \\
\hline 6W63-Isoflavone & -11.19 & -47.28 & -58.47 & -4.72 & -12.30 \\
\hline 6W4B-Coumadin & -79.84 & -34.01 & -113.85 & -16.57 & -17.84 \\
\hline
\end{tabular}




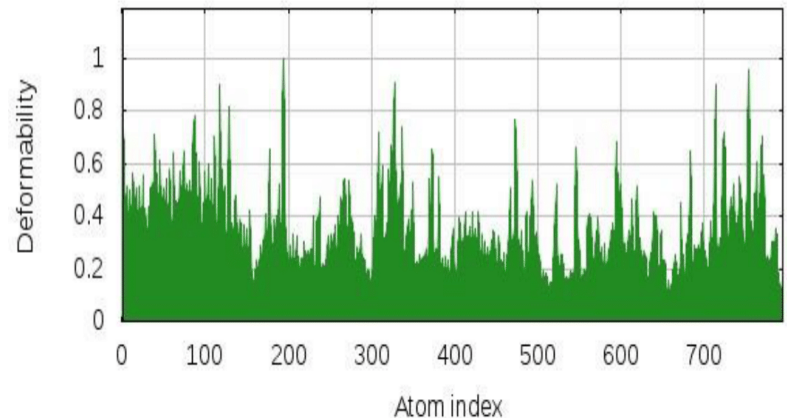

A)

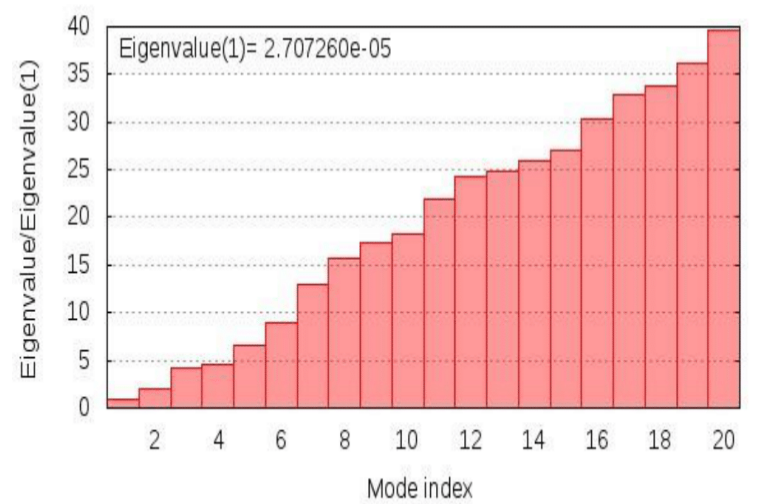

C)

The Radius of Gyration (Rg) Plot

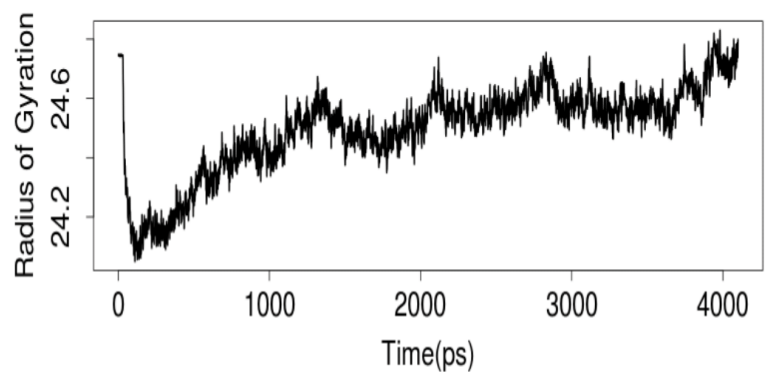

E)

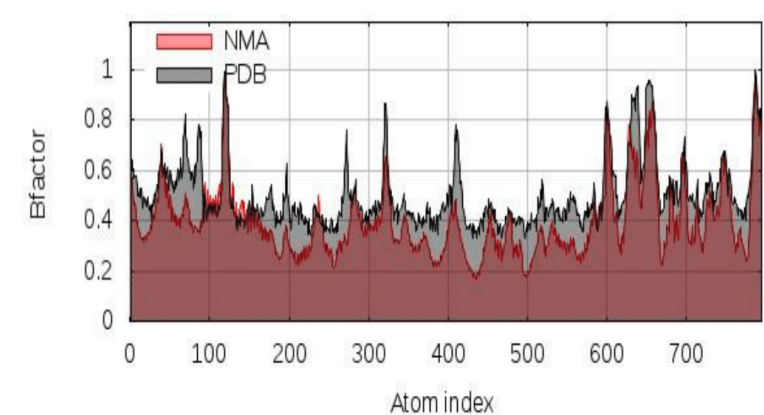

B)

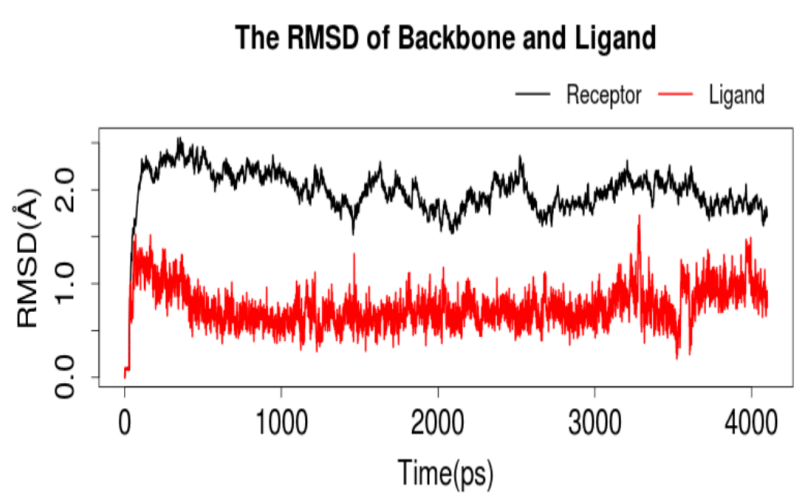

D)

The RMSF Value of Each Residue

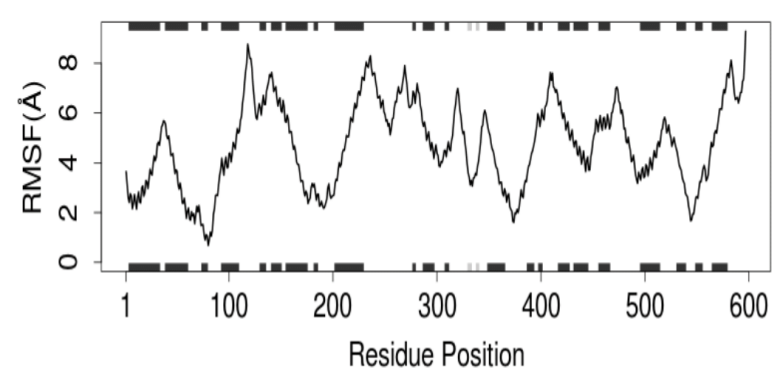

F)

Figure 4: Molecular Dynamics of 6M0J-Isoflavone: Deformability analysis(A); B factor Analysis(B); Eigen value (C); RMSD plot (D); Rg plot (E); RMSF value (F). 


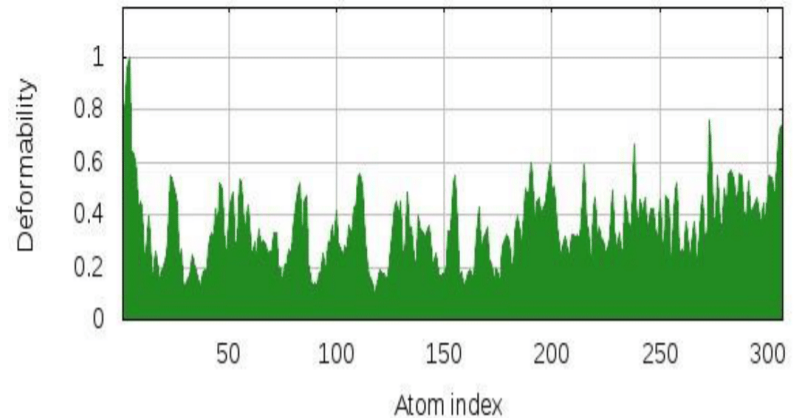

A)

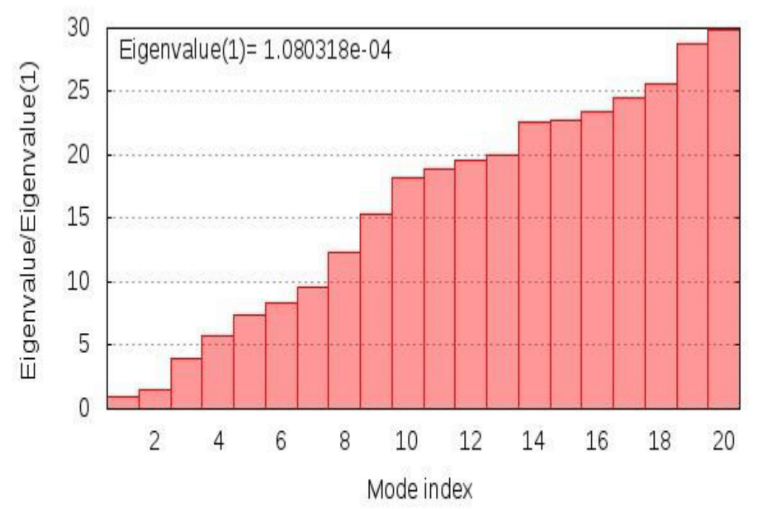

C)

The Radius of Gyration ( $\mathrm{Rg})$ Plot

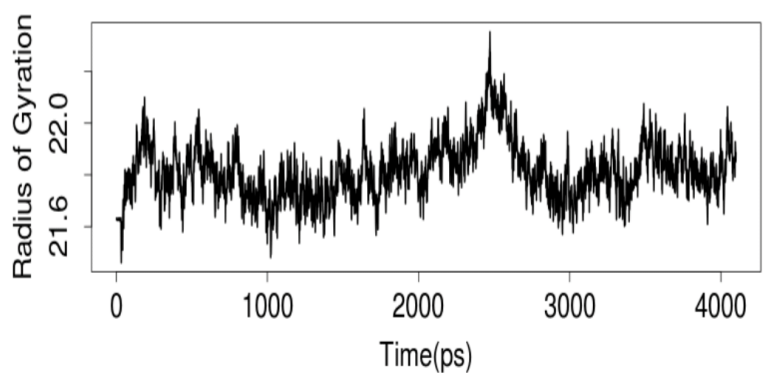

E)

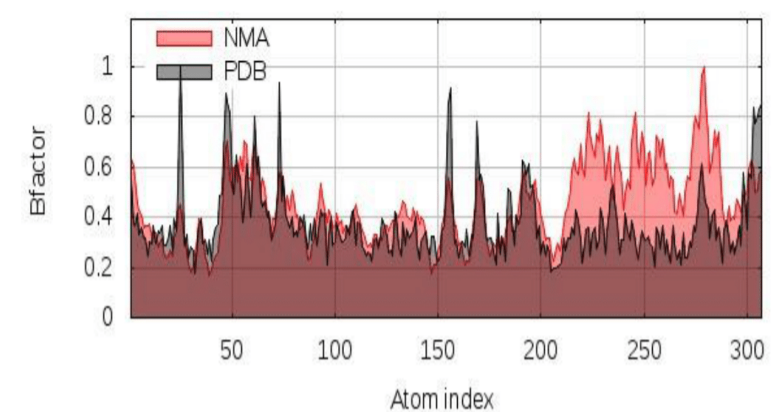

B)

The RMSD of Backbone and Ligand

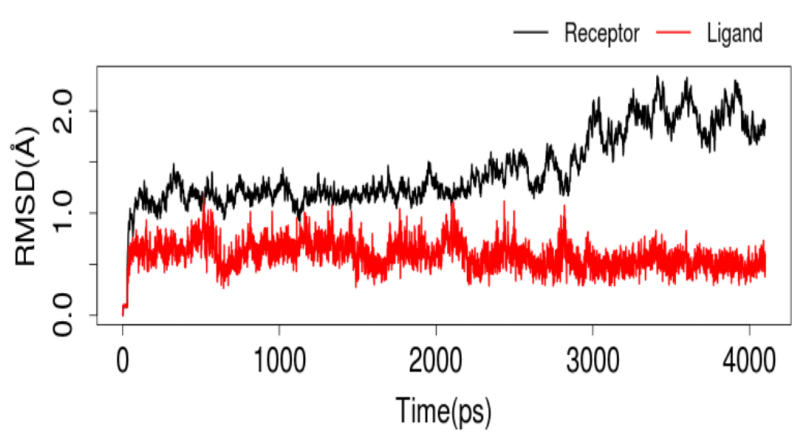

D)

The RMSF Value of Each Residue

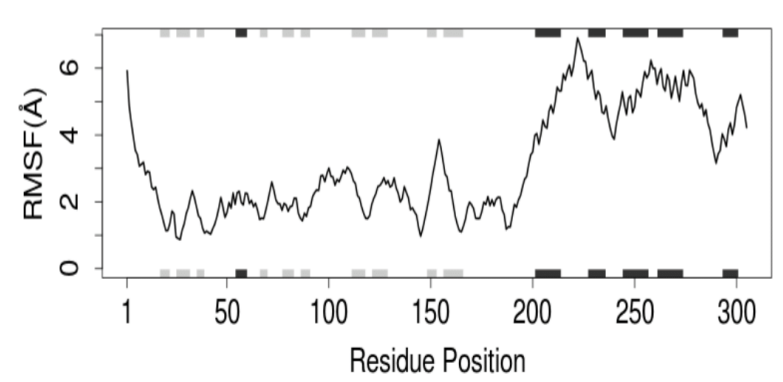

F)

Figure 5: Molecular Dynamics of 6W63-Isoflavone: Deformability analysis (A); B factor Analysis(B); Eigen value (C); RMSD plot (D); Rg plot (E); RMSF value (F). 


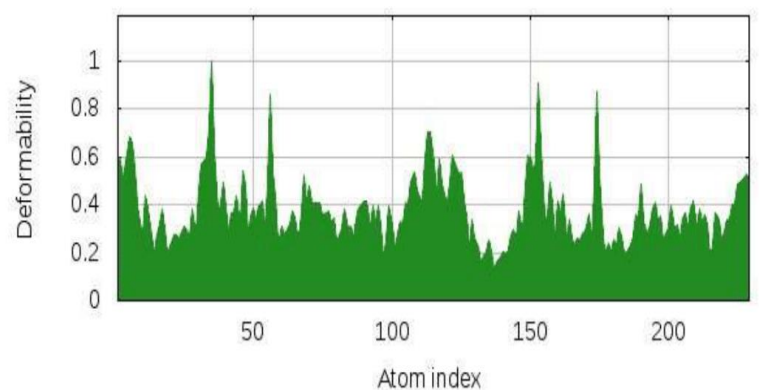

A)

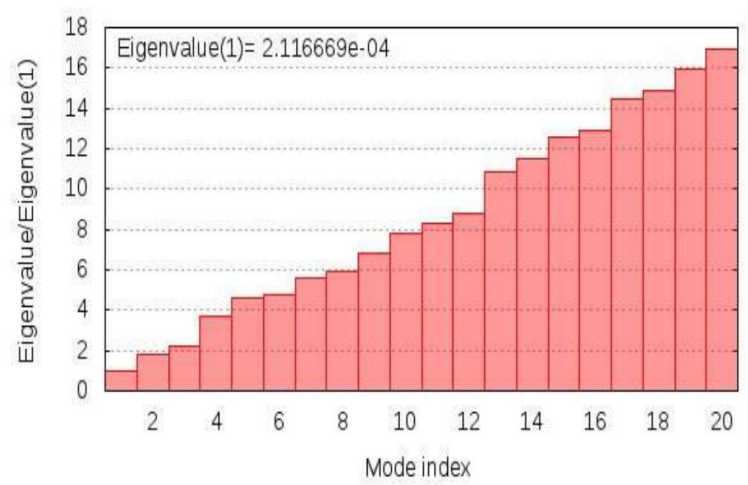

C)

The Radius of Gyration (Rg) Plot

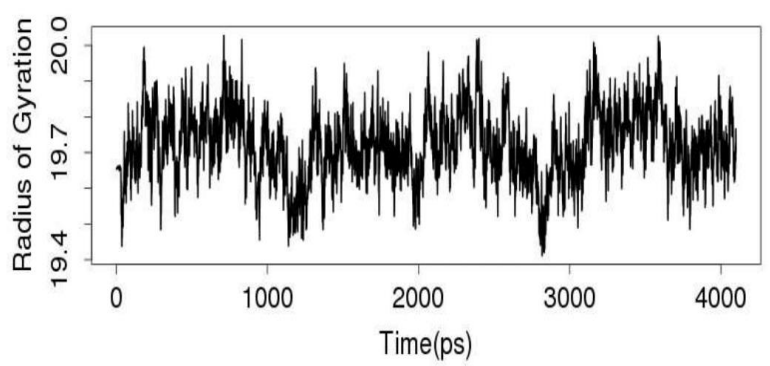

E)

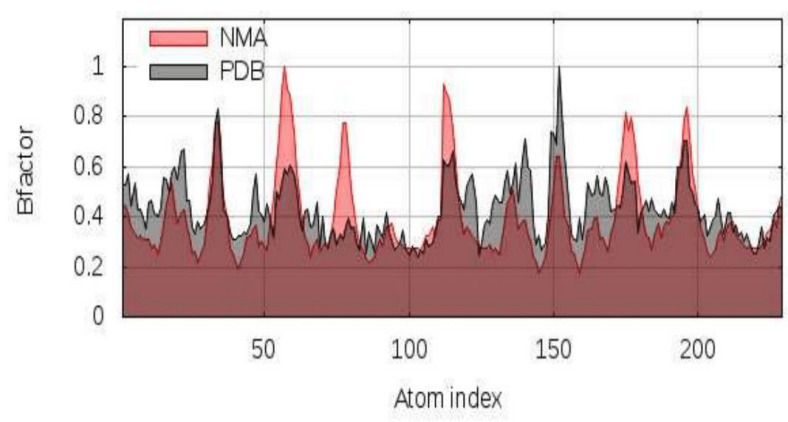

B)

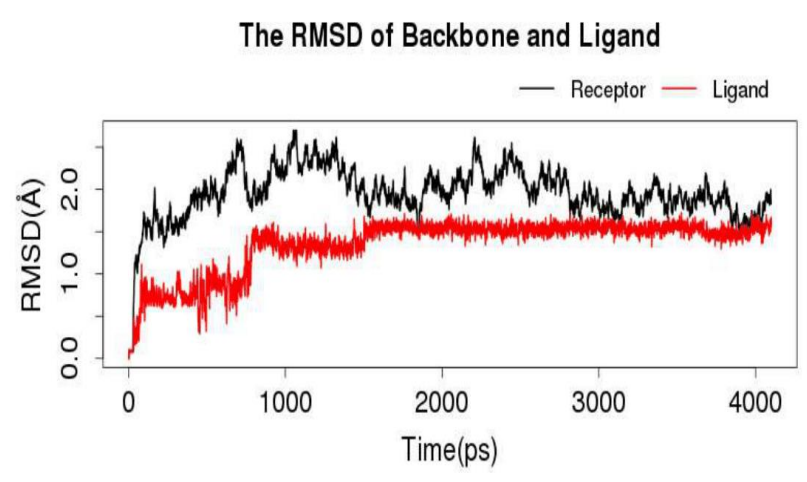

D)

The RMSF Value of Each Residue

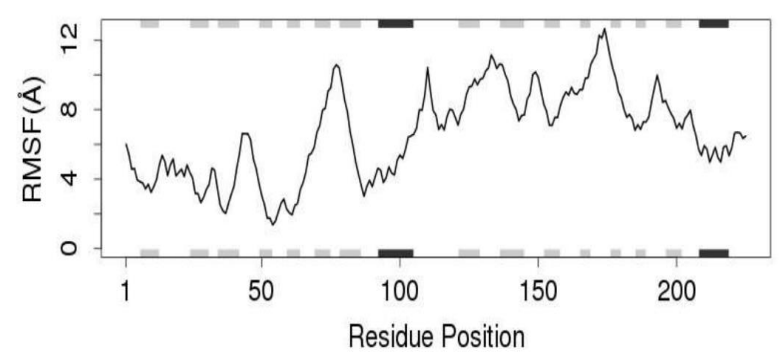

F)

Figure 6: Molecular Dynamics of 6W4B-Coumadin: Deformability analysis (A); B factor Analysis(B); Eigen value (C); RMSD plot (D); Rg plot (E); RMSF value (F). 


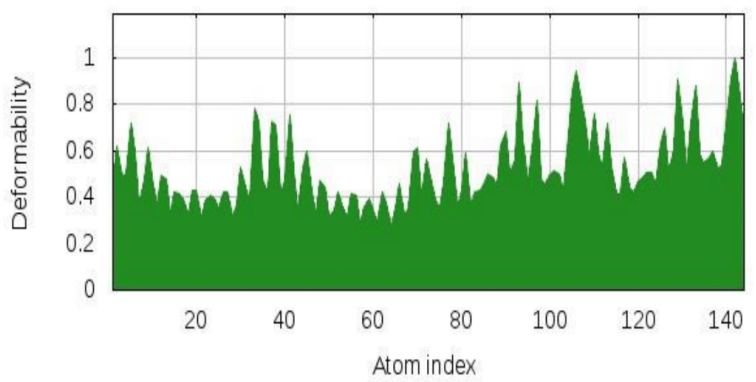

A)

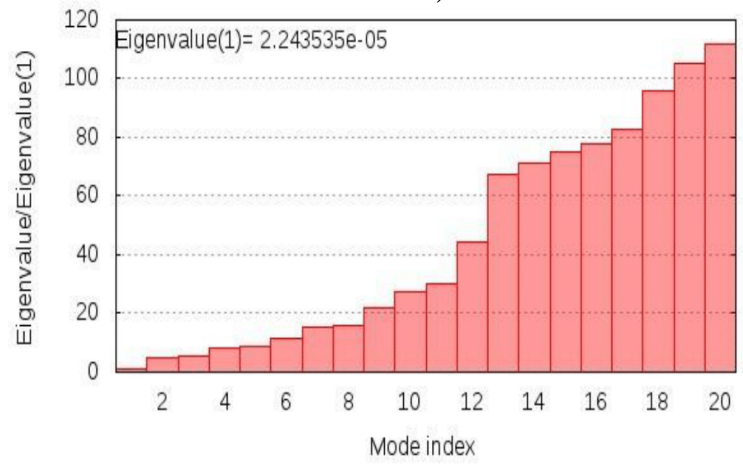

C)

The Radius of Gyration (Rg) Plot

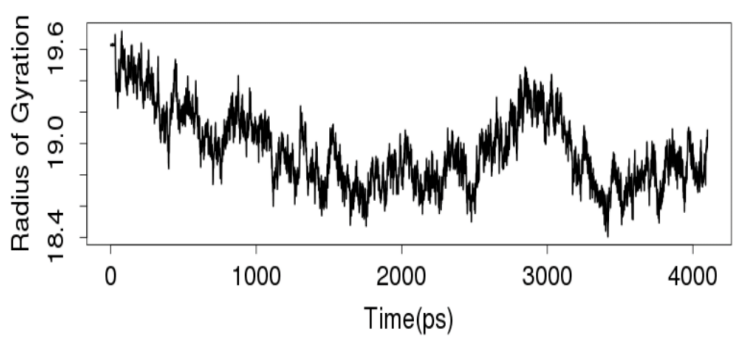

E)

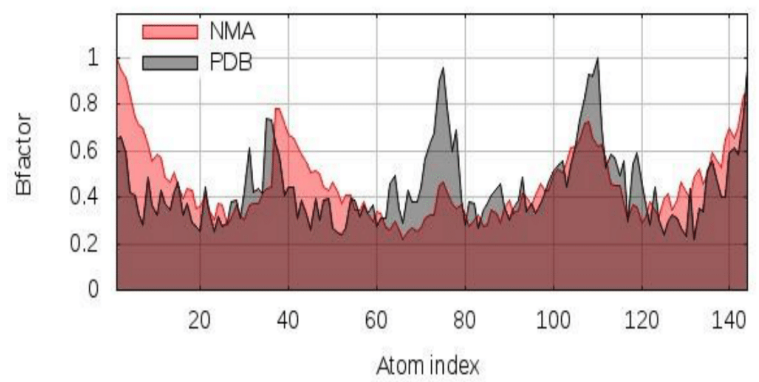

B)

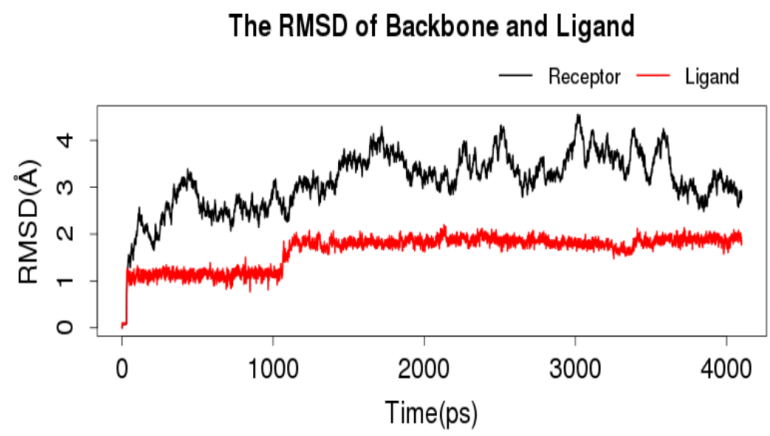

D)

The RMSF Value of Each Residue

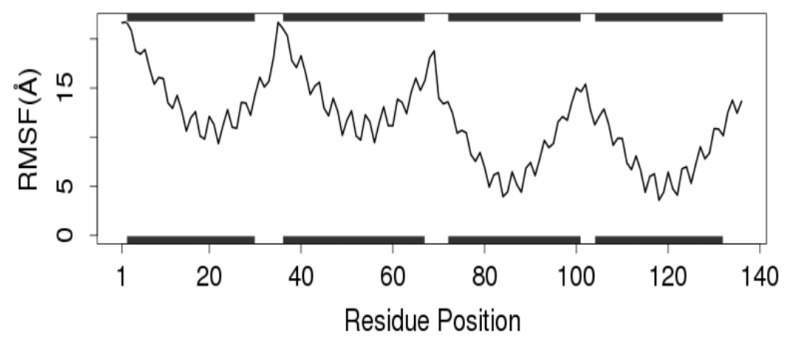

F)

Figure 7: Molecular Dynamics of 6LVN-Limonin complex: Deformability analysis (A); B factor Analysis(B); Eigen value (C); RMSD plot (D); Rg plot (E); RMSF value (F).

\subsection{ADME analysis of top drug candidates}

Drug profiles of top drug candidates were evaluated by analyzing their various ADME properties such as physicochemical parameters, pharmacokinetics, lipophilicity, water solubility and medicinal chemistry (Fig. 8 and Table 4). For all the three candidates GI absorption was high. Inhibition effects with different CYP isoforms (CYP1A2, CYP2D6, CYP2C9, CYP2C19, 
CYP3A4) showed that most of the candidates had no interaction possibility with the isoforms, except isoflavone with CYP1A2, isoflavone and coumadin with CYP2C19, and coumadin with CYP2C9. Besides, blood- brain barrier (BBB) permeation analysed by the BOILED-Egg model revealed that isoflavone and coumadin are BBB permeant, while limonin isn't a BBB permeant. Each candidate had a good water solubility, while limonin was more soluble.

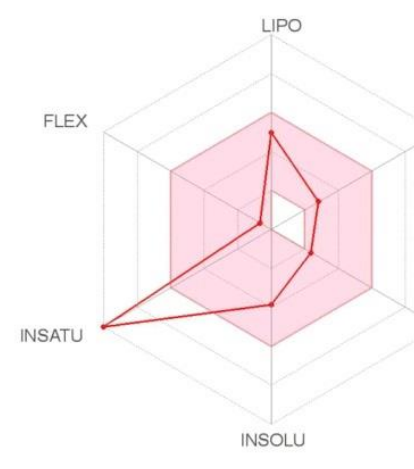

A)

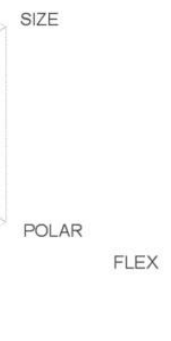

INSATU
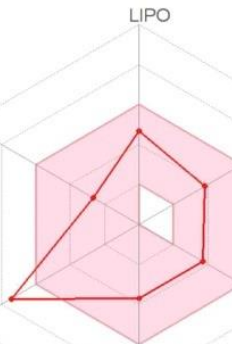

INSOLU

C)

Figure 8: ADME analysis of top three metabolites; Limonin (A), Isoflavone (B), Coumadin (C).

Table 4: Drug profile and ADME analysis of the top three metabolites against SARS-CoV-2 Proteins

\begin{tabular}{|c|c|c|c|c|}
\hline \multicolumn{2}{|l|}{ Parameter } & \multicolumn{3}{|c|}{$\begin{array}{l}\text { Top Inhibitors of SARS-CoV-2 } \\
\text { Proteins }\end{array}$} \\
\hline & & Isoflavone & Limonin & Coumadin \\
\hline \multirow{3}{*}{$\begin{array}{l}\text { Physicochemical } \\
\text { parameters }\end{array}$} & Formula & C15H10O2 & C26H30O8 & C19H16O4 \\
\hline & Molecular weight & $222.24 \mathrm{~g} / \mathrm{mol}$ & $\begin{array}{r}470.51 \\
\mathrm{~g} / \mathrm{mol}\end{array}$ & $\begin{array}{c}308.33 \\
\mathrm{~g} / \mathrm{mol}\end{array}$ \\
\hline & $\begin{array}{l}\text { No. H-bond } \\
\text { acceptors }\end{array}$ & 2 & 8 & 4 \\
\hline
\end{tabular}




\begin{tabular}{|c|c|c|c|c|}
\hline & No. H-bond donors & 0 & 0 & 1 \\
\hline & Molar Refractivity & 67.92 & 116.17 & 88.58 \\
\hline & TPSA & $30.21 \AA^{2}$ & $104.57 \AA^{2}$ & $67.51 \AA^{2}$ \\
\hline \multirow{6}{*}{ Lipophilicity } & $\log P_{\mathrm{o} / \mathrm{w}}(\mathrm{iLOGP})$ & 2.51 & 2.87 & 2.41 \\
\hline & $\log P_{\mathrm{o} / \mathrm{w}}(\mathrm{XLOGP} 3)$ & 3.18 & 177 & 2.70 \\
\hline & $\log P_{\mathrm{o} / \mathrm{w}}(\mathrm{WLOGP})$ & 3.46 & 2.81 & 3.61 \\
\hline & $\log P_{\mathrm{o} / \mathrm{w}}(\mathrm{MLOGP})$ & 2.27 & 1.45 & 2.51 \\
\hline & $\begin{array}{c}\log P_{\mathrm{o} / \mathrm{w}}(\text { SILICOS- } \\
\text { IT) }\end{array}$ & 4.04 & 3.83 & 4.36 \\
\hline & Consensus $\log P_{\mathrm{o} / \mathrm{w}}$ & 3.09 & 2.55 & 3.12 \\
\hline \multirow{9}{*}{ Pharmacokinetics } & GI absorption & High & High & High \\
\hline & BBB permeant & Yes & No & Yes \\
\hline & P-gp substrate & No & No & No \\
\hline & CYP1A2 inhibitor & Yes & No & No \\
\hline & CYP2C19 inhibitor & Yes & No & Yes \\
\hline & CYP2C9 inhibitor & No & No & Yes \\
\hline & CYP2D6 inhibitor & No & No & No \\
\hline & CYP3A4 inhibitor & No & No & No \\
\hline & $\begin{array}{l}\log K_{\mathrm{p}} \text { (skin } \\
\text { permeation) }\end{array}$ & $-5.40 \mathrm{~cm} / \mathrm{s}$ & $-7.91 \mathrm{~cm} / \mathrm{s}$ & $-6.26 \mathrm{~cm} / \mathrm{s}$ \\
\hline \multirow{5}{*}{ Water Solubility } & $\log S(\mathrm{ESOL})$ & -3.85 & -3.92 & -3.70 \\
\hline & Solubility & $\begin{array}{c}3.13 \mathrm{e}-02 \\
\mathrm{mg} / \mathrm{ml} \\
1.41 \mathrm{e}-04 \\
\mathrm{~mol} / \mathrm{l}\end{array}$ & $\begin{array}{c}5.72 \mathrm{e}-02 \\
\mathrm{mg} / \mathrm{ml} \\
1.22 \mathrm{e}-04 \\
\mathrm{~mol} / \mathrm{l}\end{array}$ & $\begin{array}{c}6.10 \mathrm{e}-02 \\
\mathrm{mg} / \mathrm{ml} \\
1.98 \mathrm{e}-04 \\
\mathrm{~mol} / \mathrm{l}\end{array}$ \\
\hline & Class & Soluble & Soluble & Soluble \\
\hline & $\begin{array}{c}\text { Log } S \text { (SILICOS- } \\
\text { IT) }\end{array}$ & -6.13 & -5.41 & -6.33 \\
\hline & Solubility & $\begin{array}{c}1.63 \mathrm{e}-04 \\
\mathrm{mg} / \mathrm{ml} ; \\
7.33 \mathrm{e}-07 \\
\mathrm{~mol} / \mathrm{l}\end{array}$ & $\begin{array}{c}1.82 \mathrm{e}-03 \\
\mathrm{mg} / \mathrm{ml} \\
3.86 \mathrm{e}-06 \\
\mathrm{~mol} / \mathrm{l}\end{array}$ & $\begin{array}{c}1.45 \mathrm{e}-04 \\
\mathrm{mg} / \mathrm{ml} \\
4.71 \mathrm{e}-07 \\
\mathrm{~mol} / \mathrm{l}\end{array}$ \\
\hline
\end{tabular}




\begin{tabular}{|c|c|c|c|c|}
\hline & Class & $\begin{array}{c}\text { Poorly } \\
\text { Soluble }\end{array}$ & $\begin{array}{c}\text { Moderately } \\
\text { soluble }\end{array}$ & $\begin{array}{c}\text { Poorly } \\
\text { Soluble }\end{array}$ \\
\hline \multirow{7}{*}{$\begin{array}{c}\text { Medicinal } \\
\text { Chemistry }\end{array}$} & Leadlikeness & $\begin{array}{c}\text { Yes; } 0 \\
\text { violation }\end{array}$ & $\begin{array}{c}\text { No; } 1 \\
\text { violation: } \\
\text { MW }>350\end{array}$ & Yes \\
\cline { 2 - 5 } & $\begin{array}{c}\text { Bioavailability } \\
\text { Score }\end{array}$ & 0.55 & 0.55 & 0.55 \\
\cline { 2 - 5 } & PAINS & 0 alert & 0 alert & 0 alert \\
\cline { 2 - 5 } & $\begin{array}{c}\text { Synthetic } \\
\text { accessibility }\end{array}$ & 2.82 & 6.49 & 3.79 \\
\hline
\end{tabular}

\subsection{Analysis of Toxicity pattern of top drug candidates}

AMES toxicity, oral Rat toxicity, skin sensitization, minnow toxicity, carcinigenecity, hepatotoxicityskin sensitization and other toxicity parameters of top drug candidateswere predicted (Table 5). The negative results of AMES test for these drug candidates indicated them as non- mutagenic. Each of these top metabolites exhibited negative outcome in hERGI and hERG II inhibitors prediction test. According to the result, Oral Rat Acute Toxicity, LD50, and Oral Rat Chronic Toxicity,LOAEL, values ranged from 1.726 to $3.452(\mathrm{~mol} / \mathrm{kg})$ and from 0.99 to $1.911(\mathrm{log}$ $\mathrm{mg} / \mathrm{kg} \_$bw/day), respectively. Besides, the negative results of hepatotoxicityand skin sensitisation tests suggested these metabolites as non-hepatotoxic and insensitive to skin. Minnow Toxicity values predicted them non- toxic, as the values were more than $-0.3 \log \mathrm{mM}$. Furthermore, carcinogenicity evaluated by admetSAR was negative for each of three top drug candidates, claimed them as non carcinogens. 
Table 5: Toxicity pattern of top three metabolites.

\begin{tabular}{|c|c|c|c|}
\hline Toxicity Parameters & Isoflavone & Limonin & Coumadin \\
\hline AMES Test & No & No & No \\
\hline Max. Tolerated Dose (log mg/kg/day) & 0.107 & -0.508 & 0.294 \\
\hline hERG I inhibitor & No & No & No \\
\hline hERG II inhibitors & No & No & No \\
\hline Oral Rat Acute Toxicity, LD50 (mol/kg) & 1.726 & 3.452 & 1.773 \\
\hline $\begin{array}{l}\text { Oral Rat Chronic Toxicity,LOAEL (log } \\
\text { mg/kg_bw/day) }\end{array}$ & 0.99 & 1.911 & 1.081 \\
\hline Hepatotoxicity & No & No & No \\
\hline Carcinogens & Non-carcinogens & Non-carcinogens & Non-carcinogens \\
\hline Skin Sensitisation & No & No & No \\
\hline T. pyriformis Toxicity $(\log \mu \mathrm{g} / \mathrm{L})$ & 1.244 & 0.286 & 0.591 \\
\hline Minnow Toxicity $(\log \mathrm{mM})$ & 0.603 & 0.446 & 0.034 \\
\hline
\end{tabular}

\subsection{Prediction of drug targets and available drug molecules from DrugBank}


Drug targets of top metabolites revealed that they were mostly from the classes of family A G protein-coupled receptor, protease, kinase and nuclear receptor (Fig. 9 and Table 6). Limonin showed Delta opioid receptor, Kappa Opioid receptor, Cathepsin K, Cathepsin S and Leucine-rich repeat serine/threonine-protein kinase 2 as targets, while for isoflavone Monoamine oxidase B, Estrogen receptor $\beta$, Adenosine A1 receptor, Adenosine A2a receptor, Estrogen-related receptor alpha and Epidermal growth factor receptor erbB1 were targets. Besides, G-protein coupled receptor 35, Subtilisin/kexin type 7, MAP kinase ERK2 and Serine/threonine-protein kinase PIM1 were drug targets for coumadin. Biologically active small compounds against SARS-CoV-2 were predicted from DrugBank by conducting ligand-based virtual screening (Table 7). Warfarin (DB00682) and Phenprocoumon (DB00946) are the two approved drugs that were found analogous to coumadin. Apart from these, coumadin showed another analog 4-Hydroxy-3-[(1s)3-Oxo-1-Phenylbutyl]-2h-Chromen-2-One (DB02507) which is in experimental stage. Moreover, isoflavone revealed three experimental analogs, namely isoformononetin (DB04202), (1s)-1(phenoxymethyl)propyl methylphosphonochloridoate (DB08419) and (rp,sp)-o-(2r)-(1phenoxybut-2-yl)-methylphosphonic acid chloride (DB07990), while limonin showed no similar bioactive molecule.

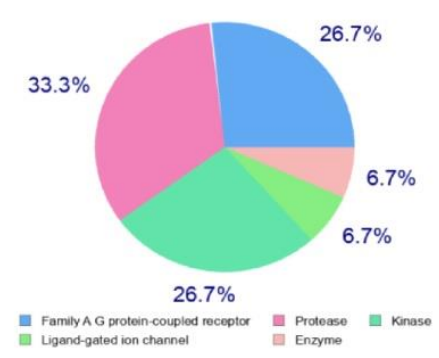

A)

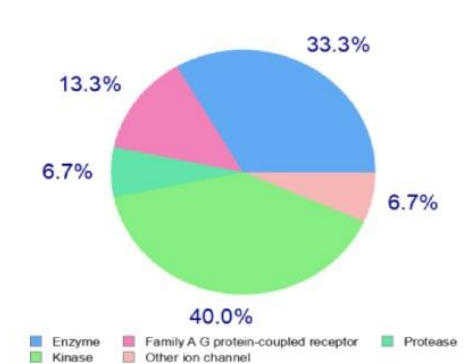

C)

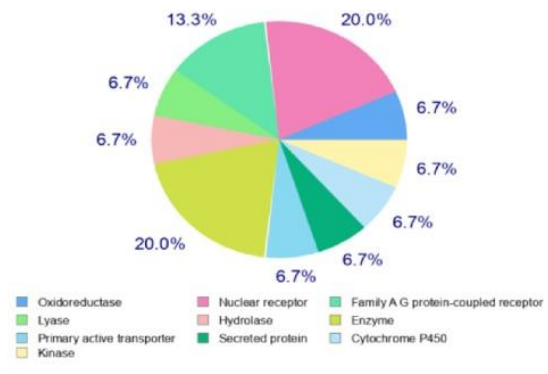

B)

Figure 9: Prediction of drug Targets for top three metabolites; Limonin (A), Isoflavone (B), Coumadin $(\mathrm{C})$. 
Table 6: Predicted drug targets for Limonin, Isoflavone and Coumadin.

\begin{tabular}{|c|c|c|c|c|c|}
\hline $\begin{array}{l}\text { Metabolite } \\
\text { s }\end{array}$ & Drug Targets & $\begin{array}{l}\text { Common } \\
\text { Name }\end{array}$ & $\begin{array}{l}\text { Uniprot } \\
\text { ID }\end{array}$ & ChEMBL ID & Target Class \\
\hline \multirow[t]{5}{*}{\begin{tabular}{|l|} 
Limonin \\
\end{tabular}} & $\begin{array}{l}\text { Delta opioid } \\
\text { receptor }\end{array}$ & OPRD1 & P41143 & CHEMBL236 & $\begin{array}{ll}\text { Family A G } \\
\text { protein- } \\
\text { coupled }\end{array}$ \\
\hline & $\begin{array}{l}\text { Kappa Opioid } \\
\text { receptor }\end{array}$ & OPRK1 & P41145 & CHEMBL237 & $\begin{array}{ll}\text { Family } & \text { A G } \\
\text { protein- } & \\
\text { coupled } & \\
\text { receptor } & \end{array}$ \\
\hline & Cathepsin K & CTSK & P43235 & CHEMBL268 & Protease \\
\hline & Cathepsin S & CTSS & P25774 & CHEMBL2954 & Protease \\
\hline & $\begin{array}{l}\text { Leucine-rich } \\
\text { repeat } \\
\text { serine/threonine- } \\
\text { protein kinase } 2\end{array}$ & LRRK2 & Q5S007 & $\begin{array}{l}\text { CHEMBL107510 } \\
4\end{array}$ & Kinase \\
\hline \multirow[t]{4}{*}{ Isoflavone } & $\begin{array}{l}\text { Monoamine } \\
\text { oxidase B }\end{array}$ & MAOB & P27338 & CHEMBL2039 & $\begin{array}{l}\text { Oxidoreductas } \\
\text { e }\end{array}$ \\
\hline & $\begin{array}{l}\text { Estrogen } \\
\text { receptor } \beta\end{array}$ & ESR2 & Q92731 & CHEMBL242 & $\begin{array}{l}\text { Nuclear } \\
\text { receptor }\end{array}$ \\
\hline & $\begin{array}{l}\text { Adenosine A1 } \\
\text { receptor }\end{array}$ & ADORA1 & P30542 & CHEMBL226 & $\begin{array}{ll}\text { Family A G } & \text { protein- } \\
\text { coupled } & \\
\text { receptor } & \end{array}$ \\
\hline & $\begin{array}{l}\text { Adenosine A2a } \\
\text { receptor }\end{array}$ & $\begin{array}{l}\text { ADORA2 } \\
\text { A }\end{array}$ & P29274 & CHEMBL251 & $\begin{array}{l}\text { Family } A \quad G \\
\text { protein- }\end{array}$ \\
\hline
\end{tabular}




\begin{tabular}{|c|c|c|c|c|c|}
\hline & & & & & $\begin{array}{l}\text { coupled } \\
\text { receptor }\end{array}$ \\
\hline & $\begin{array}{l}\text { Estrogen-related } \\
\text { receptor alpha }\end{array}$ & ESRRA & P11474 & CHEMBL3429 & $\begin{array}{l}\text { Nuclear } \\
\text { receptor }\end{array}$ \\
\hline & $\begin{array}{l}\text { Epidermal } \\
\text { growth factor } \\
\text { receptor erbB1 }\end{array}$ & EGFR & P00533 & CHEMBL203 & Kinase \\
\hline \multirow[t]{4}{*}{ Coumadin } & $\begin{array}{l}\text { G-protein } \\
\text { coupled receptor } \\
35\end{array}$ & GPR35 & $\begin{array}{l}\text { Q9HC9 } \\
7\end{array}$ & $\begin{array}{l}\text { CHEMBL129326 } \\
7\end{array}$ & $\begin{array}{lll}\text { Family } & \text { A } \quad G \\
\text { protein- } & & \\
\text { coupled } & & \\
\text { receptor } & & \end{array}$ \\
\hline & $\begin{array}{l}\text { Subtilisin/kexin } \\
\text { type } 7\end{array}$ & PCSK7 & Q16549 & CHEMBL2232 & Protease \\
\hline & $\begin{array}{l}\text { MAP kinase } \\
\text { ERK2 }\end{array}$ & MAPK1 & P28482 & CHEMBL4040 & Kinase \\
\hline & $\begin{array}{l}\text { Serine/threonine } \\
\text {-protein kinase } \\
\text { PIM1 }\end{array}$ & PIM1 & P11309 & CHEMBL2147 & Kinase \\
\hline
\end{tabular}

Table 7: Structural similar bioactive molecules from drug bank

\begin{tabular}{|c|l|l|l|l|}
\hline \multirow{5}{*}{ Drugs } & $\begin{array}{c}\text { Similar } \\
\text { structure } \\
\text { Drug } \\
\text { bank id }\end{array}$ & \multicolumn{1}{|c|}{ Name } & Score & Status \\
\hline \multirow{5}{*}{ Coumadin } & DB00682 & Warfarin & 0.998 & Approved \\
\cline { 2 - 5 } & DB00946 & Phenprocoumon & 0.959 & Approved \\
\cline { 2 - 5 } Isoflavone & $\begin{array}{l}\text { 4-Hydroxy-3-[(1s)-3-Oxo-1-Phenylbutyl]- } \\
\text { 2h-Chromen-2-One }\end{array}$ & 0.998 & Experimental \\
\cline { 2 - 5 } & DB04202 & Isoformononetin & 0.393 & Experimental \\
\cline { 2 - 6 } & DB07419 & $\begin{array}{l}\text { (1S)-1-(PHENOXYMETHYL)PROPYL } \\
\text { METHYLPHOSPHONOCHLORIDOATE }\end{array}$ & 0.134 & Experimental \\
& $\begin{array}{l}\text { (RP,SP)-O-(2R)-(1-PHENOXYBUT-2- } \\
\text { YL)-METHYLPHOSPHONIC ACID } \\
\text { CHLORIDE }\end{array}$ & 0.126 & Experimental \\
\hline Limonin & No similarity Found & & \\
\hline
\end{tabular}




\section{Discussion}

As both infection rate and mortality have not been reduced due to SARS-CoV-2, it has been too much important for researchers to develop appropriate drugs to inhibit this virus. Regarding to this matter, scientists are working immensely to develop drugs to combat this disease (Lake, 2020). But till now there are no specific drugs to be used for the treatment of this disease. Although some candidates are within the investigational phase, numerous of them raised questionable issues (Fang et al., 2020). Besides different types of chemical agents, plant-derived natural products play a significant role in the development of drug candidates (Joseph et al., 2017). In this study, attempts were taken to assess some plant-derived metabolites as inhibitory agents of SARS-CoV-2 based on their binding affinities to the four key proteins of the pathogen. The study suggested that among different plant metabolites, isoflavone, limonin and Coumadin may play most effective role against four major proteins of SARS-CoV-2.

Drug discovery is the step-by- step process by which new candidates of drugs are discovered. In case of drug discovery, the contribution of computational biology is praiseworthy. This sector can speed up the identification of drug targets, screening and refinement of drug candidates. Computer based analysis also assists in determination of toxicity patterns of drug candidates. By this way, one can represent the binding possibilities of promising small molecules as ligands/inhibitors (Sekhar, 2020). Several phytomolecules like Luteolin, Quercetin, Baicalein and Kaempferol are potential antiviral agents against various threatening viruses including HIV, Dengue, H5N1 influenza A virus, CHIKV, Coxsackie virus etc (Ghildiyal et al., 2020). Different in silico techniques have also been employed to test putative drug candidates against SARS-CoV-2 (Habbu et al., 2009; Parvez et al., 2020). A recent study claimed the use of alpha-ketoamide as a Mpro (Main protease protein) inhibitor of this virus to determine it's efficiency as a drug candidate. However, main protease proteins or RNA-dependent RNA polymerase of SARS-CoV-2 were used as probable drug targets by most of these experiments. In this study, we focused on some plant metabolites against major proteins of SARS-CoV-2 such as main proteases (6W63), RNA binding protein $(6 \mathrm{~W} 4 \mathrm{~B})$, spike receptor binding domain (6M0J) and HR2 domain (6LVN) through molecular docking strategy (Chang et al.,2010). Proteases cleave and transform polyproteins into 
mature non-structural proteins (NSPs) (Hilgenfeld, 2014). Thus the main protease of SARS-CoV2 is a key enzyme for this virus as it is needed for cleavage ofpolyproteins translated from the viral RNA to make them functional (Anand et al., 2003). On the other hand, the entry of coronavirus into host cells is mediated by the transmembrane spike $(\mathrm{S})$ glycoprotein that forms homotrimers protruding from the viral surface. $\mathrm{S}$ protein composed of two subunits functionally active for binding to the host cell receptor $\left(S_{1}\right.$ subunit $)$ and viral and cellular membranes fusion $\left(S_{2}\right.$ subunit). After the interaction of the receptor-binding subunit to the receptor, the HR1 and HR2 domains of the membrane fusion subunit attach with each other and build a six-helix bundle and this conformational modification causes the close apposition of the fusion peptide resulting in viruscell membrane fusion (Moore et al., 2003). Thus, spike protein binds to human ACE2 and CLEC4M/DC-SIGNR receptors and facilitates the internalization of the virus into the host cell's endosomes that induces structural changes in the S glycoprotein (Tortorici and Veesler, 2019). By inhibiting these proteins, therefore, it is possible to fight SARS-CoV-2 and that's why all these proteins have become strong pharmacological target in terms of SARS-CoV-2.

Docking result of this study revealed that 3 plant metabolites such as Isoflavone, Limonin and Coumadin have maximum scores and low binding energy for each macromolecule. Isoflavone showed highest binding affinity for spike receptor binding protein $(52.98 \mathrm{kcal} / \mathrm{mol})$ and main protease protein $(-59.55 \mathrm{kcal} / \mathrm{mol})$ (Figure 2). On the contrary, Limonin and Coumadin had highest binding affinity for HR2 domain $(-28.89 \mathrm{kcal} / \mathrm{mol})$ and RNA binding protein $(-45.62 \mathrm{kcal} / \mathrm{mol})$ respectively (Figure 2). The top candidates scored either close or even lower than alpha ketoamide, the positive control for this study. Isoflavones are a subclass of flavonoids, the significant phytoestrogens naturally reside in plants. Isoflavones are largelyfound in soybeans (5$30 \mathrm{mg} / 100 \mathrm{~g}$ ). It is known that topoisomerase enzyme is essential for replication of microorganisms. Isoflavone inhibits the catalytic activity of the enzyme by stabilizing the covalent topoisomerase II-DNA cleavage complex and thus microbial growth can be stopped (Yao et al., 2008). Isoflavones also can reduce the infectivity of various viruses affecting humans and animals, such as adenovirus, human immunedeficiency virus, herpes simplex virus, rotavirus, and porcine reproductive and respiratory syndrome virus. They have been shown to influence viral attachment, entrance, replication, translation and formation of certain virus envelope glycoprotein complexes. Isoflavones have also effect on numerous host cell signaling processes, mentioning gene transcription factors induction and cytokines secretion (Lin et al., 1999). Limonene and perillyl 
alcohol along with their metabolites (particularlyperillic acid and its methyl ester) possess bioactivities such as antiviral, antitumor, antibacterial and anti-inflammatory agents. Limonin suppresses HIV-1 LTR transcription and viral replication and also has a vital function to inhibit herpes simplex virus (Abd et al., 2019). Coumadin is one such natural compound that is a potential drug candidate owing to its properties of stability, solubility, and low toxicity (Sagor et al., 2010). Various evidences showed its inhibitory function against several viruses such as HIV, Enterovirus 71 (EV71), Influenza and coxsackievirus A16 (CVA16). It either inhibits essential proteins of viral entry, replication and infection or regulates cellular pathways such as Akt-Mtor (mammalian target of rapamycin), NF- $\mathrm{B}$ (nuclear factor kappa-light-chain-enhancer of activated B cells), and antioxidative pathway including NrF-2 (The nuclear factor erythroid 2 (NFE2)-related factor 2) (Wang et al., 2012).

In the present study, the molecular interactions of top metabolites with SARS-CoV-2 key proteins disclosed (Fig. 2 and Table 2). The catalytic domain of SARS-CoV-2 main protease protein is the location where the binding sites for each ligand occupied (Yang et al., 2003). From different common binding residues, His41 and Cys145 are responsible for the catalytic dyad formation and act as a substrate recognition site (Yang et al., 2003; Wu et al., 2020). The top drug candidates fitted well into the active pocket of MPP where numerous hydrophobic amino acids such as Met49, Gly143, Gly205, Cys145, Met165, Pro168, Ala191 and Ala 396 constitute a relatively hydrophobic environment, which may be favorable for conformational stabilization (Wu et al., 2020).

The amino acid positions 13 to 24 of HR2 Domain were most significant for binding with ligands where Asp17, Arg18, Glu21 and Lys24 were binding sites for each of the three top metabolites. Besides, the regions from 91 to 99 and from 196 to 210 were revealed as top surface hotspots for spike receptor binding domain in which Leu95, Gln98, Gly205, Asp206, Tyr207, Glu208, Val209 and Asn210 were prevalent. The ligands experienced greatest binding affinity for 50-75 positions of Nsp9 (Non-structural protein-9) RNA binding protein, and for 141-168 and 186-192 regions of SARS-Cov-2 main protease (6W63). Nsp9 protein has some significant binding sites (39-73 region) that are characterized by positively charged, glycine rich $\beta$-loops, which were suggested to be involved in RNA binding (Litter et al., 2020).Moreover, distinct domains of SARS-CoV-2 spike protein were our targets, which are necessary in the viral entry into the host cell (Shang et al., 2020). The study may be helpful to reveal the main drug target hotspots and medicinal chemistry of the investigational drugs which are under trials at present against SARS-CoV-2. 
The deformability analysis for all studied complex shows unsignificant hinges (Figure4:A,5:A;6:A,7:A).. The B factor analysis refers no significant loops were present in the complexes (Figure4:B,5:B;6:B,7:B).. The eigen values were higher which shows complex resistance to deformation and remains stable (Figure4:C,5:C;6:C,7:C)..The RMSD values for all the structures were lesser than $2 \AA$ and weren't show any undesirable repulsion(Figure4:D,5:D;6:D,7:D)..RMSF values shows a regular pattern of atomic fluctuations during the molecular dynamics stimulation(Figure4:F,5:F;6:F,7:F) . The Rg value were higher for all studied component. This means the ligand interacting to the proteins were significantly influenced the structural activity of protein (Figure4:E,5:E;6:E,7:E).

ADME data can be measured experimentally or predicted computationally, both of them deliver a key insight how a drug will ultimately be treated or accepted by the body. Although a drug lead may exhibit remarkable efficacy in vitro, poor ADME results usually obstruct its development. Computational strategies anticipate potential ADME and toxicity problems and help to reduce the number of experiments that require animals. Therefore, to investigate the drug profiles of the top drug candidates, ADME analysis was conducted. However, no metabolites showed any unexpected consequences that could curtail their drug likeness properties. Drug targets of top drug candidates mostly belonged to the classes of family A G protein-coupled receptor, protease, kinase and nuclear receptor (Fig. 9 and Table 6). Again all of these three metabolites showed solubility which is an important property of a drug candidate. The toxicity prediction results of our study showedthat all three drug candidates are non-carcinogenic, non-mutagenic,insensitive to skin and alsoshowedno hepatotoxicity. All the drug candidates are friendly to heart asthey showed negative result in hERGIand hERG II inhibitors prediction test. Overall the toxicity prediction test suggested those drugs are safe to take as a medication to treat Covid-19. Ligand based drug similarity analysis result revealed three structural analogs of Coumadin. Among them two (Warfarin and Phenprocoumon) are approved and another one (4-Hydroxy-3-[(1s)-3-Oxo-1Phenylbutyl]-2h-Chromen-2-One) is still in experimental stage. Both Warfarin and Phenprocoumon are used to treat blood clots (such as in deep vein thrombosis-DVT or pulmonary embolus-PE) and/or to prevent new clots from forming in your body. Prevention of detrimental blood clots causes to lessen the risk ofstroke or heart attack (Bandali et al., 2014).

As it is known that COVID 19 can also cause heart attack, this medications can be used as a supportive agent in this disease. Furthermore. isoflavone has three structurally similar analogs which are in 
experimental stage. Thus from the above discussion, it can be expected that all these top three plant metabolites can be used as potential drug candidates against SARS-CoV-2.

\section{References}

Zhu, N., Zhang, D., Wang, W., Li, X., Yang, B., Song, J., Zhao, X., Huang, B., Shi, W., Lu, R. and Niu, P., 2020. A novel coronavirus from patients with pneumonia in China, 2019. New England Journal of Medicine, 382(8), pp. 727-733.

Chen, Y., Liu, Q. and Guo, D., 2020. Emerging coronaviruses: genome structure, replication, and pathogenesis. Journal of medical virology, 92(4), pp.418-423.

Woolf, S.H., Chapman, D.A., Sabo, R.T., Weinberger, D.M. and Hill, L., 2020. Excess deaths from COVID-19 and other causes, March-April 2020. Jama, 324(5), pp.510-513.

Magnani, C., Azzolina, D., Gallo, E., Ferrante, D. and Gregori, D., 2020. How Large Was the Mortality Increase Directly and Indirectly Caused by the COVID-19 Epidemic? An Analysis on All-Causes Mortality Data in Italy. International Journal of Environmental Research and Public Health, 17(10), p.3452.

Zhou, D., Dai, S.M. and Tong, Q., 2020. COVID-19: a recommendation to examine the effect of hydroxychloroquine in preventing infection and progression. Journal of Antimicrobial Chemotherapy.

Zhou, D., S.-M. Dai, Q. Tong, COVID-19: a recommendation to examine the effect of hydroxychloroquine in preventing infection and progression., J. Antimicrob. Chemother. dkaa114 (2020).

Guo YR, Cao QD, Hong ZS, Tan YY, Chen SD, Jin HJ et al. The origin, transmission and clinical therapies on coronavirus disease 2019 (COVID-19) outbreak - an update on the status. Mil Med Res. 2020;7(1):11. Published 2020 Mar 13. doi:10.1186/s40779-02000240-0.

Pyrc, K., Dijkman, R., Deng, L., Jebbink, M.F., Ross, H.A., Berkhout, B. and Van der Hoek, L., 2006. Mosaic structure of human coronavirus NL63, one thousand years of evolution. Journal of molecular biology, 364(5), pp.964-973. 
De Wit, E., Van Doremalen, N., Falzarano, D. and Munster, V.J., 2016. SARS and MERS: recent insights into emerging coronaviruses. Nature Reviews Microbiology, 14(8), pp.523534.

Chan, J.F.W., Yuan, S., Kok, K.H., To, K.K.W., Chu, H., Yang, J., Xing, F., Liu, J., Yip, C.C.Y., Poon, R.W.S. and Tsoi, H.W., 2020. A familial cluster of pneumonia associated with the 2019 novel coronavirus indicating person-to-person transmission: a study of a family cluster. The Lancet, 395(10223), pp.514-523.

Hoffmann, M., Kleine-Weber, H., Schroeder, S., Krüger, N., Herrler, T., Erichsen, S., Schiergens, T.S., Herrler, G., Wu, N.H., Nitsche, A. and Müller, M.A., 2020. SARS-CoV2 cell entry depends on ACE2 and TMPRSS2 and is blocked by a clinically proven protease inhibitor. Cell. 181(2), pp.271-280.e8.

Wan, Y., Shang, J., Graham, R., Baric, R.S. and Li, F., 2020. Receptor recognition by the novel coronavirus from Wuhan: an analysis based on decade-long structural studies of SARS coronavirus. Journal of virology, 94(7).

Velavan, T.P. and Meyer, C.G., 2020. The COVID-19 epidemic. Tropical medicine \& international health, 25(3), p.278.

Munster, V.J., Koopmans, M., van Doremalen, N., van Riel, D. and de Wit, E., 2020. A novel coronavirus emerging in China-key questions for impact assessment. New England Journal of Medicine, 382(8), pp.692-694.

Huang, C., Wang, Y., Li, X., Ren, L., Zhao, J., Hu, Y., Zhang, L., Fan, G., Xu, J., Gu, X. and Cheng, Z., 2020. Clinical features of patients infected with 2019 novel coronavirus in Wuhan, China. The lancet, 395(10223), pp.497-506.

Dhama, K., Sharun, K., Tiwari, R., Dadar, M., Malik, Y.S., Singh, K.P. and Chaicumpa, W., 2020. COVID-19, an emerging coronavirus infection: advances and prospects in designing and developing vaccines, immunotherapeutics, and therapeutics. Human vaccines \& immunotherapeutics, 16(6), pp.1232-1238..

Koc, S., Isgor, B.S., Isgor, Y.G., Shomali Moghaddam, N. and Yildirim, O., 2015. The potential medicinal value of plants from Asteraceae family with antioxidant defense enzymes as biological targets. Pharmaceutical biology, 53(5), pp.746-751. 
Kumar, A., Choudhir, G., Shukla, S.K., Sharma, M., Tyagi, P., Bhushan, A. and Rathore, M., 2020. Identification of phytochemical inhibitors against main protease of COVID-19 using molecular modeling approaches. Journal of Biomolecular Structure and Dynamics, (just-accepted), pp.1-21. Ozougwu, J.C. and Eyo, J.E., 2011. Evaluation of the activity of Zingiber officinale (ginger) aqueous extracts on alloxan-induced diabetic rats. Pharmacologyonline, 1, pp.258-269.

Salehi, B., Venditti, A., Sharifi-Rad, M., Kręgiel, D., Sharifi-Rad, J., Durazzo, A., Lucarini, M., Santini, A., Souto, E.B., Novellino, E. and Antolak, H., 2019. The therapeutic potential of apigenin. International journal of molecular sciences. 20(6), p.1305.

Okujagu, T.F., Etatuvie, S.O., Eze, I., Jimoh, B., Nwokereke, C., Mbaoji, C., Mohammed, Z., 2008. Medicinal plant of Nigeria, north-west Nigeria. Nigerian Journal of Natural Product \& Medicine, 1771(1), pp32-34.

Lawal, I.O., Uzokwe, N.E., Igboanugo, A.B.I., Adio, A.F., Awosan, E.A., Nwogwugwu, J.O., Faloye, B., Olatunji, B.P. and Adesoga, A.A., 2010. Ethno medicinal information on collation and identification of some medicinal plants in Research Institutes of South-west Nigeria. African Journal of Pharmacy and Pharmacology, 4(1), pp.001-007.

Odugbemi, T., 2006. Outlines and pictures of medicinal plants from Nigeria. University of Lagos Press, Lagos, pp.283.

Shaba, P., Pandey, N.N., Sharma, O.P., Rao, J.R. and Singh, R.K., 2012. Anti-trypanosomal activity of Piper nigrum L (Black pepper) against Trypanosoma evansi. J. Vet. Adv, 2(4), pp.161167.

Moongkarndi, P., Kosem, N., Luanratana, O., Jongsomboonkusol, S. and Pongpan, N., 2004. Antiproliferative activity of Thai medicinal plant extracts on human breast adenocarcinoma cell line. Fitoterapia, 75(3-4), pp.375-377.

Obho, G., 2006. Antioxidant and Antimicrobial Properties of Ethanolic Extract of Ocimum gratissimum Linn. Leaves, 1(1), pp.47-53.

Amic, D., Davidovic-Amic, D., Beslo, D., Trinajstic, N., 2003. Structure-Radical scavenging activity relationship of flavonoids. Croatica chemica acta, 76(1), pp.55-61. 
Ogunniran, K.O., 2009. Antibacterial effects of extracts of Ocimum gratissimum and piper guineense on Escherichia coli and Staphylococcus aureus. African Journal of Food Science, 3(3), pp.77-81.

Iroha, I.R., Amadi, E.S., Nwuzo, A.C. and Afiukwa, F.N., 2009. Evaluation of the antibacterial activity of extracts of Sida acuta against clinical isolates of Staphylococcus aureus isolated from human immunodeficiency virus/acquired immunodeficiency syndrome patients. Research Journal of Pharmacology, 3(2), pp.22-25.

Farombi, E.O., Ogundipe, O. and Moody, J.O., 2001. Antioxidant and anti-inflammatory activities of Mallotus oppositifolium in model systems. African journal of medicine and medical sciences, 30(3), pp.213-215.

O'Rourke, C., Byres, M., Delazar, A., Kumarasamy, Y., Nahar, L., Stewart, F. and Sarker, S.D., 2005. Hirsutanonol, oregonin and genkwanin from the seeds of Alnus glutinosa (Betulaceae). Biochemical systematics and ecology, 33 (7), pp.749-752.

Prabu, G.R., Gnanamani, A. and Sadulla, S., 2006. Guaijaverin-a plant flavonoid as potential antiplaque agent against Streptococcus mutans. Journal of Applied Microbiology, 101(2), pp.487495.

Onwukaeme, N.D., 1995. Medicinal plant of Nigeria Natural Medicine Development Agency Federal Ministry of Science and Technology. Phytotherapy research, 9, pp.306-308.

Zhao, J., Wang, J., Chen, Y. and Agarwal, R., 1999. Anti-tumor-promoting activity of a polyphenolic fraction isolated from grape seeds in the mouse skin two-stage initiation-promotion protocol and identification of procyanidin B5-3'-gallate as the most effective antioxidant constituent. Carcinogenesis, 20(9), pp.1737-1745.

Kokwaro, J.O., 1993. Medicinal Plants of East Africa, 2nd Edition. East African Literature Bureau, Nairobi.

Sofowora, A., 2008. Medicinal Plants and Traditional Medicine in Africa. 3rd. Ibadan, Nigeria: Spectrum Books. 
Mourtzinos, I., Konteles, S., Kalogeropoulos, N. and Karathanos, V.T., 2009. Thermal oxidation of vanillin affects its antioxidant and antimicrobial properties. Food Chemistry, 114(3), pp.791797.

Kim, J.H., Lee, H.O., Cho, Y.J., Kim, J., Chun, J., Choi, J., Lee, Y. and Jung, W.H., 2014. A vanillin derivative causes mitochondrial dysfunction and triggers oxidative stress in Cryptococcus neoformans. PloS one, 9(2), p.e89122.

Rose, P.W., Prlić, A., Altunkaya, A., Bi, C., Bradley, A.R., Christie, C.H., Costanzo, L.D., Duarte, J.M., Dutta, S., Feng, Z. and Green, R.K., 2016. The RCSB protein data bank: integrative view of protein, gene and 3D structural information. Nucleic acids research, 45(D1), pp.D271-D281.

Kim, S., Thiessen, P.A., Bolton, E.E., Chen, J., Fu, G., Gindulyte, A., Han, L., He, J., He, S., Shoemaker, B.A. and Wang, J., 2016. PubChem substance and compound databases. Nucleic acids research, 44(D1), pp.D1202-D1213.

O'Boyle, N.M., Banck, M., James, C.A., Morley, C., Vandermeersch, T. and Hutchison, G.R., 2011. Open Babel: An open chemical toolbox. Journal of cheminformatics, 3(1), p.33.

Pinzi, L. and Rastelli, G., 2019. Molecular docking: Shifting paradigms in drug discovery. International journal of molecular sciences, 20(18), p.4331.

Meng, X.Y., Zhang, H.X., Mezei, M. and Cui, M., 2011. Molecular docking: a powerful approach for structure-based drug discovery. Current computer-aided drug design, 7(2), pp.146-157.

Schneidman-Duhovny, D., Inbar, Y., Nussinov, R. and Wolfson, H.J., 2005. PatchDock and SymmDock: servers for rigid and symmetric docking. Nucleic acids research,33(suppl_2), pp.W363-W367.

Zhang, L., Lin, D., Sun, X., Curth, U., Drosten, C., Sauerhering, L., Becker, S., Rox, K. and Hilgenfeld, R., 2020. Crystal structure of SARS-CoV-2 main protease provides a basis for design of improved $\alpha$-ketoamide inhibitors. Science, 368(6489), pp.409-412. 
Mashiach, E., Schneidman-Duhovny, D., Andrusier, N., Nussinov, R. and Wolfson, H.J., 2008. FireDock: a web server for fast interaction refinement in molecular docking. Nucleic acids research,36(suppl_2), pp.W229-W232.

Wang, Q., He, J., Wu, D., Wang, J., Yan, J. and Li, H., 2015. Interaction of $\alpha$-cyperone with human serum albumin: Determination of the binding site by using Discovery Studio and via spectroscopic methods. Journal of Luminescence, 164, pp.81-85.

DeLano, W.L., 2002. Pymol: An open-source molecular graphics tool. CCP4 Newsletter on protein crystallography, 40(1), pp.82-92.

Yang, J.F., Wang, F., Chen, Y.Z., Hao, G.F. and Yang, G.F., 2019. LARMD: integration of bioinformatic resources to profile ligand-driven protein dynamics with a case on the activation of estrogen receptor. Briefings in Bioinformatics.

Raha, K. and Merz, K.M., 2005. Large-scale validation of a quantum mechanics based scoring function: predicting the binding affinity and the binding mode of a diverse set of protein- ligand complexes. Journal of medicinal chemistry, 48(14), pp.4558-4575.

Hou, T., Wang, J., Li, Y. and Wang, W., 2011. Assessing the performance of the MM/PBSA and MM/GBSA methods. 1. The accuracy of binding free energy calculations based on molecular dynamics simulations. Journal of chemical information and modeling, 51(1), pp.69-82.

Hao, G.F., Zhu, X.L., Ji, F.Q., Zhang, L., Yang, G.F. and Zhan, C.G., 2009. Understanding the mechanism of drug resistance due to a codon deletion in protoporphyrinogen oxidase through computational modeling. The Journal of Physical Chemistry B, 113(14), pp.4865-4875.

Pan, Y., Gao, D. and Zhan, C.G., 2008. Modeling the catalysis of anti-cocaine catalytic antibody: competing reaction pathways and free energy barriers. Journal of the American Chemical Society, 130(15), pp.5140-5149.

López-Blanco, J.R., Aliaga, J.I., Quintana-Ortí, E.S. and Chacón, P., 2014. iMODS: internal coordinates normal mode analysis server. Nucleic acids research, 42(W1), pp.W271-W276..

Case, D.A., Cheatham III, T.E., Darden, T., Gohlke, H., Luo, R., Merz Jr, K.M., Onufriev, A., Simmerling, C., Wang, B. and Woods, R.J., 2005. The Amber biomolecular simulation programs. Journal of computational chemistry, 26(16), pp.1668-1688. 
Roe, D.R. and Cheatham III, T.E., 2013. PTRAJ and CPPTRAJ: software for processing and analysis of molecular dynamics trajectory data. Journal of chemical theory and computation, 9(7), pp.3084-3095.

Vugmeyster, Y., Harrold, J. and Xu, X., 2012. Absorption, distribution, metabolism, and excretion (ADME) studies of biotherapeutics for autoimmune and inflammatory conditions. The AAPS journal, 14(4), pp.714-727.

Lin, J., Sahakian, D.C., De Morais, S.M., Xu, J.J., Polzer, R.J. and Winter, S.M., 2003. The role of absorption, distribution, metabolism, excretion and toxicity in drug discovery. Current topics in medicinal chemistry, 3(10), pp.1125-1154.

Daina, A., Michielin, O. and Zoete, V., 2017. SwissADME: a free web tool to evaluate pharmacokinetics, drug-likeness and medicinal chemistry friendliness of small molecules. Scientific reports, 7, p.42717.

Daina, A. and Zoete, V., 2016. A boiled-egg to predict gastrointestinal absorption and brain penetration of small molecules. ChemMedChem, 11(11), p.1117-1121.

Pires, D.E., Blundell, T.L. and Ascher, D.B., 2015. pkCSM: predicting small-molecule pharmacokinetic and toxicity properties using graph-based signatures. Journal of medicinal chemistry, 58(9), pp.4066-4072.

Cheng, F., Li, W., Zhou, Y., Shen, J., Wu, Z., Liu, G., Lee, P.W. and Tang, Y., 2012. admetSAR: a comprehensive source and free tool for assessment of chemical ADMET properties. Journal of Chemical Information and Modeling, 52(11), pp.3099-3105.

Daina, A., Michielin, O. and Zoete, V., 2019. SwissTargetPrediction: updated data and new features for efficient prediction of protein targets of small molecules. Nucleic acids research, 47(W1), pp.W357-W364.

Zoete, V., Daina, A., Bovigny, C. and Michielin, O., 2016. SwissSimilarity: a web tool for low to ultra high throughput ligand-based virtual screening.

Lake, M.A., 2020. What we know so far: COVID-19 current clinical knowledge and research. Clinical Medicine, 20(2), p.124. 
Fang, Y., Zhang, H., Xie, J., Lin, M., Ying, L., Pang, P. and Ji, W., 2020. Sensitivity of chest CT for COVID-19: comparison to RT-PCR. Radiology, 296(2), pp.E115-E117.

Joseph, J., Bhaskaran, R., Kaliraj, M., Muthuswamy, M. and Suresh, A., 2017. Molecular Docking of Phytoligands to the viral protein receptor P. monodon Rab7. Bioinformation, 13(4), pp.116-121.

Sekhar, T., 2020. Molecular Docking and Virtual Screening based prediction of potential drugs for COVID-19. Combinatorial Chemistry \& High Throughput Screening.

Ghildiyal, R., Prakash, V., Chaudhary, V.K., Gupta, V. and Gabrani, R., 2020. Phytochemicals as Antiviral Agents: Recent Updates. In Plant-derived Bioactives (pp. 279-295). Springer, Singapore.

Habbu, P.V., Mahadevan, K.M., Shastry, R.A. and Manjunatha, H., 2009. Antimicrobial activity of flavanoid sulphates and other fractions of Argyreia speciosa (Burm. f) Boj. Indian Journal of Experimental Biolog. 47(2), pp.121-128.

Parvez, M., Alam, S., Karim, M., Hasan, M., Jaman, J., Karim, Z., Tahsin, T., Hasan, M. and Hosen, M.J., 2020. Prediction of potential inhibitors for RNA-dependent RNA polymerase of SARS-CoV-2 using comprehensive drug repurposing and molecular docking approach. arXiv preprint arXiv:2004.07086.

Chang, M.W., Ayeni, C., Breuer, S. and Torbett, B.E., 2010. Virtual screening for HIV protease inhibitors: a comparison of AutoDock 4 and Vina. PloS one, 5(8), p.e11955.

Hilgenfeld, R., 2014. From SARS to MERS: crystallographic studies on coronaviral proteases enable antiviral drug design. The FEBS journal, 281(18), pp.4085-4096.

Anand, K., Ziebuhr, J., Wadhwani, P., Mesters, J.R. and Hilgenfeld, R., 2003. Coronavirus main proteinase (3CLpro) structure: basis for design of anti-SARS drugs. Science, 300(5626), pp.17631767. 
Moore, J.P. and Doms, R.W., 2003. The entry of entry inhibitors: a fusion of science and medicine. Proceedings of the National Academy of Sciences, 100(19), pp.10598-10602.

Tortorici, M.A. and Veesler, D., 2019. Structural insights into coronavirus entry. In Advances in virus research (Vol. 105, pp. 93-116). Academic Press.

Yao-Kouassi, P.A., Alabdul Magid, A., Richard, B., Martinez, A., Jacquier, M.J., Caron, C., Le Magrex Debar, E., Gangloff, S.C., Coffy, A.A. and Zeches-Hanrot, M., 2008. Isoflavonoid glycosides from the roots of Baphia bancoensis. Journal of natural products, 71(12), pp.20732076.

Lin, Y.M., Flavin, M.T., Schure, R., Chen, F.C., Sidwell, R., Barnard, D.I., Huffmann, J.H. and Kern, E.R., 1999. Antiviral activities of biflavonoids. Planta medica, 65(02), pp.120-125.

Abd, A.J., Al-Shammarie Ahmed, M. and Abd, A.H.H., 2019. Antiviral activity of limonin against Newcastle Disease virus in vitro. Research Journal of Biotechnology, 14 (Special Issue I), pp.320328.

Sagar, S., Kaur, M. and Minneman, K.P., 2010. Antiviral lead compounds from marine sponges. Marine drugs, 8(10), pp.2619-2638.

Wang, C.Y., Huang, S.C., Zhang, Y., Lai, Z.R., Kung, S.H., Chang, Y.S. and Lin, C.W., 2012. Antiviral ability of Kalanchoe gracilis leaf extract against enterovirus 71 and coxsackievirus A16. Evidence-Based Complementary and Alternative Medicine, 2012, pp1-13.

Yang, H., Yang, M., Ding, Y., Liu, Y., Lou, Z., Zhou, Z., Sun, L., Mo, L., Ye, S., Pang, H. and Gao, G.F., 2003. The crystal structures of severe acute respiratory syndrome virus main protease and its complex with an inhibitor. Proceedings of the National Academy of Sciences, 100(23), pp.13190-13195. 
Wu, C., Liu, Y., Yang, Y., Zhang, P., Zhong, W., Wang, Y., Wang, Q., Xu, Y., Li, M., Li, X. and Zheng, M., 2020. Analysis of therapeutic targets for SARS-CoV-2 and discovery of potential drugs by computational methods. Acta Pharmaceutica Sinica B, 10(5), pp.766-788.

Littler, D.R., Gully, B.S., Colson, R.N. and Rossjohn, J., 2020. Crystal structure of the SARSCoV-2 non-structural protein 9, Nsp9. Iscience, p.101258.

Shang, J., Wan, Y., Luo, C., Ye, G., Geng, Q., Auerbach, A. and Li, F., 2020. Cell entry mechanisms of SARS-CoV-2. Proceedings of the National Academy of Sciences, 117(21), pp.11727-11734.

Bandali, F., Thomas, Z. and Gozzo, Y., 2014. 1205: Conservative management of massive rivaroxaban and enoxaparin overdose. Critical Care Medicine, 42(12), p.A1642.

Azim, K.F., Ahmed, S.R., Banik, A., Khan, M.M.R., Deb, A. and Somana, S.R., 2020. Screening and druggability analysis of some plant metabolites against SARS-CoV-2: An integrative computational approach. Informatics in Medicine Unlocked, p.100367.

Banik, A., Ahmed, S.R., Sajib, E.H., Deb, A., Sinha, S. and Azim, K.F., 2020. Identification of potential inhibitory analogs of metastasis tumor antigens (MTAs) using bioactive compounds: revealing therapeutic option to prevent malignancy. bioRxiv.

Rahman, M.R., Banik, A., Chowdhury, I.M., Sajib, E. and Sarkar, S., 2020. Virtual Screening of Some Antivirals That Can Be Repurposed As Potential Effective Drugs against SARS-CoV-2.

Banik, A., Mondal, M.F., Khan, M.M.R., Ahmed, S.R. and Hasan, M.M., 2020. Screening and potent applicability analysis of commonly used pesticides against desert locust: an integrative entomo-informatics approach. bioRxiv.

Supplementary File 1: Molecular docking results of metabolites with different SARS$\mathrm{CoV}-2$ proteins/protein domains 


\begin{tabular}{|c|c|c|c|c|c|c|c|}
\hline $\begin{array}{l}\text { Macromolecule } \\
\text { s }\end{array}$ & $\begin{array}{l}\text { Ligands/ } \\
\text { Metabolites }\end{array}$ & $\begin{array}{l}\text { Solution } \\
\text { Number }\end{array}$ & $\begin{array}{l}\text { Global } \\
\text { energy }\end{array}$ & ACE & HB & Score & Area \\
\hline \multirow[t]{27}{*}{$\begin{array}{l}\text { HR2 } \\
\text { Domain(6LVN) }\end{array}$} & $\begin{array}{ll}\text { Allyl } & \text { propyl } \\
\text { disulfide } & \end{array}$ & 2 & -13.14 & -0.77 & 0.00 & 2194 & 233.70 \\
\hline & Apigenin & 5 & -23.22 & -1.71 & 0.00 & 3012 & 314.00 \\
\hline & Aristolochic acid & 1 & -21.51 & 0.90 & 0.00 & 5580 & 664.60 \\
\hline & Artocarpesin & 4 & -20.51 & -1.17 & 0.00 & 3608 & 391.60 \\
\hline & Ascorbic acid & 2 & -26.96 & -2.49 & 0.00 & 3528 & 411.20 \\
\hline & Asparagine & 1 & -15.80 & -5.74 & 0.00 & 1914 & 195.50 \\
\hline & Camphene & 8 & -17.75 & -6.48 & 0.00 & 2446 & 276.80 \\
\hline & Chavicine & 2 & -24.61 & -2.55 & 0.00 & 3826 & 437.60 \\
\hline & Chrysoeriol & 2 & -27.18 & 0.32 & 0.00 & 4638 & 509.30 \\
\hline & Cianidanol & 9 & -20.40 & -8.71 & 0.00 & 2194 & 246.20 \\
\hline & Citronellal & 3 & -26.14 & -0.49 & 0.00 & 3796 & 445.80 \\
\hline & Cleomiscosin B & 8 & -24.62 & 2.82 & 0.00 & 3766 & 430.60 \\
\hline & Coumadin & 10 & -26.38 & -0.92 & 0.00 & 3656 & 413.80 \\
\hline & Dihydromorin & 6 & -23.51 & -1.55 & 0.00 & 3054 & 323.60 \\
\hline & Flavylium & 1 & -24.55 & -0.75 & 0.00 & 4152 & 457.30 \\
\hline & Genkwanin & 6 & $\begin{array}{l}-19.67 \\
\end{array}$ & -6.69 & 0.00 & 2182 & 244.00 \\
\hline & Geraniol & 5 & -20.90 & -0.85 & 0.00 & 3156 & 360.50 \\
\hline & Gingerol & 4 & -24.66 & -0.44 & 0.00 & 3588 & 423.40 \\
\hline & Hydrocyanic acid & 6 & -16.13 & -5.70 & 0.00 & 2062 & 232.40 \\
\hline & Isoflavone & 7 & -25.73 & 1.68 & 0.00 & 4274 & 554.70 \\
\hline & Limonin & 1 & -28.89 & -0.36 & 0.00 & 4186 & 471.90 \\
\hline & Myrcene & 1 & -21.36 & -0.23 & 0.00 & 3100 & 336.80 \\
\hline & Norartocarpeti & 1 & -19.02 & 1.44 & 0.00 & 3214 & 366.70 \\
\hline & Paucine & 2 & -19.75 & 2.56 & 0.00 & 3428 & 376.40 \\
\hline & Procyanidin & 1 & -20.75 & -0.54 & 0.00 & 3132 & 320.20 \\
\hline & Quinine & 5 & -23.85 & -8.57 & 0.00 & 3028 & 384.40 \\
\hline & Reserpine & 4 & -6.16 & 3.19 & -0.23 & 1468 & 150.20 \\
\hline
\end{tabular}




\begin{tabular}{|c|c|c|c|c|c|c|c|}
\hline & Riboflavin & 4 & -16.80 & -0.38 & 0.00 & 2440 & 274.00 \\
\hline & Steppogenin & 4 & -15.11 & -4.67 & 0.00 & 1826 & 197.20 \\
\hline & Stigmasterol & 10 & -22.14 & -7.17 & 0.00 & 2910 & 390.80 \\
\hline & Triterpenoids & 4 & -16.86 & -5.71 & 0.00 & 1894 & 203.00 \\
\hline & Vanillin & 5 & -21.96 & -9.28 & 0.00 & 3204 & 383.00 \\
\hline & Yohimbine & 4 & -20.27 & 0.11 & 0.00 & 3178 & 343.20 \\
\hline \multirow{23}{*}{$\begin{array}{ll}\text { Spike receptor } \\
\text { binding } \\
(6 \mathrm{M} 0 \mathrm{~J})\end{array}$} & $\begin{array}{ll}\text { Allyl } & \text { propyl } \\
\text { disulfide } & \end{array}$ & 5 & -26.92 & -8.05 & 0.00 & 3126 & 416.00 \\
\hline & Apigenin & 1 & -35.13 & -8.87 & 0.00 & 4284 & 545.10 \\
\hline & Aristolochic acid & 6 & -43.39 & -10.89 & 0.00 & 6404 & 865.00 \\
\hline & Artocarpesin & 1 & -36.03 & -7.60 & 0.00 & 4832 & 582.00 \\
\hline & Ascorbic acid & 4 & -38.36 & -9.51 & 0.00 & 4310 & 491.70 \\
\hline & Asparagine & 4 & -25.15 & -7.53 & 0.00 & 2672 & 367.60 \\
\hline & Camphene & 5 & -29.84 & -7.82 & 0.00 & 3438 & 400.30 \\
\hline & Chavicine & 4 & -44.57 & -11.52 & 0.00 & 4458 & 600.50 \\
\hline & Chrysoeriol & 1 & -47.87 & -13.10 & 0.00 & 5696 & 684.50 \\
\hline & Cianidanol & 5 & -31.09 & -11.67 & 0.00 & 2952 & 338.30 \\
\hline & Citronellal & 10 & -52.48 & -13.47 & 0.00 & 4454 & 623.10 \\
\hline & Cleomiscosin B & 1 & -44.11 & -10.95 & 0.00 & 5482 & 631.70 \\
\hline & Coumadin & 10 & -45.91 & -13.47 & 0.00 & 4968 & 624.50 \\
\hline & Dihydromorin & 2 & -35.12 & -9.45 & 0.00 & 3926 & 477.40 \\
\hline & Flavylium & 4 & -51.37 & -11.93 & 0.00 & 4788 & 645.90 \\
\hline & Genkwanin & 3 & -29.35 & -9.41 & 0.00 & 3010 & 434.80 \\
\hline & Geraniol & 9 & -40.66 & -9.13 & 0.00 & 4054 & 553.80 \\
\hline & Gingerol & 1 & -42.42 & -11.53 & 0.00 & 4956 & 584.70 \\
\hline & Hydrocyanic acid & 7 & -26.88 & -7.37 & 0.00 & 2648 & 331.50 \\
\hline & Isoflavone & 1 & -52.98 & -13.56 & 0.00 & 6254 & 764.30 \\
\hline & Limonin & 9 & -41.87 & -5.42 & 0.00 & 4476 & 590.80 \\
\hline & Myrcene & 7 & -35.10 & -10.14 & 0.00 & 3594 & 445.50 \\
\hline & Norartocarpeti & 6 & -37.84 & -4.03 & 0.00 & 3780 & 491.30 \\
\hline
\end{tabular}




\begin{tabular}{|c|c|c|c|c|c|c|c|}
\hline & Paucine & 1 & -39.56 & -9.88 & 0.00 & 4462 & 509.40 \\
\hline & Procyanidin & 2 & -35.44 & -10.20 & 0.00 & 3922 & 467.90 \\
\hline & Quinine & 5 & -38.49 & -10.17 & 0.00 & 3702 & 449.80 \\
\hline & Reserpine & 3 & -22.92 & 1.62 & -2.27 & 2314 & 258.30 \\
\hline & Riboflavin & 5 & -26.93 & -7.16 & 0.00 & 3242 & 418.80 \\
\hline & Steppogenin & 6 & -28.22 & -6.60 & 0.00 & 2598 & 300.20 \\
\hline & Stigmasterol & 2 & -44.24 & -13.07 & 0.00 & 3968 & 483.60 \\
\hline & Triterpenoids & 9 & -26.83 & $\begin{array}{l}-6.94 \\
\end{array}$ & 0.00 & 2432 & 287.90 \\
\hline & Vanillin & 8 & -45.56 & -10.57 & 0.00 & 3962 & 534.40 \\
\hline & Yohimbine & 5 & -37.53 & -4.45 & 0.00 & 3898 & 501.50 \\
\hline $\begin{array}{ll}\text { Nsp9 } & \text { (Non- } \\
\text { structural } & \end{array}$ & $\begin{array}{ll}\text { Allyl } & \text { propyl } \\
\text { disulfide } & \end{array}$ & 3 & -26.17 & -7.11 & 0.00 & 2846 & 371.40 \\
\hline protein-9) RNA & Apigenin & 3 & -33.66 & -9.62 & 0.00 & 3652 & 452.20 \\
\hline binding protein & Aristolochic acid & 9 & -32.78 & -12.96 & 0.00 & 5954 & 799.40 \\
\hline (6W4B) & Artocarpesin & 8 & -38.83 & -12.50 & 0.00 & 4086 & 498.60 \\
\hline & Ascorbic acid & 7 & -39.58 & -12.06 & 0.00 & 4092 & 489.80 \\
\hline & Asparagine & 2 & -28.30 & $\begin{array}{l}-7.44 \\
\end{array}$ & 0.00 & 2538 & 328.60 \\
\hline & Camphene & 1 & -30.59 & -7.82 & 0.00 & 3234 & 407.20 \\
\hline & Chavicine & 5 & -45.05 & -14.85 & 0.00 & 4154 & 539.80 \\
\hline & Chrysoeriol & 10 & -38.41 & -12.50 & 0.00 & 4936 & 600.40 \\
\hline & Cianidanol & 7 & -28.79 & -10.78 & 0.00 & 2480 & 305.50 \\
\hline & Citronellal & 6 & -43.99 & -12.52 & 0.00 & 4550 & 557.80 \\
\hline & Cleomiscosin B & 9 & -36.53 & -13.16 & 0.00 & 4502 & 513.50 \\
\hline & Coumadin & 1 & -45.62 & -14.28 & 0.00 & 4890 & 581.20 \\
\hline & Dihydromorin & 10 & -48.04 & -13.63 & 0.00 & 3410 & 412.80 \\
\hline & Flavylium & 3 & -42.72 & -11.02 & 0.00 & 4654 & 577.70 \\
\hline & Genkwanin & 5 & -33.37 & -11.04 & 0.00 & 2616 & 360.30 \\
\hline & Geraniol & 6 & -47.30 & -14.27 & 0.00 & 3846 & 480.20 \\
\hline & Gingerol & 7 & -36.55 & -11.99 & 0.00 & 4358 & 480.30 \\
\hline & Hydrocyanic acid & 2 & -25.70 & $\begin{array}{l}-6.44 \\
\end{array}$ & 0.00 & 2522 & 332.60 \\
\hline
\end{tabular}




\begin{tabular}{|c|c|c|c|c|c|c|c|}
\hline & Isoflavone & 6 & -40.96 & -7.94 & 0.00 & 5358 & 748.70 \\
\hline & Limonin & 4 & -42.57 & -10.74 & 0.00 & 4388 & 570.80 \\
\hline & Myrcene & 7 & -43.99 & -12.56 & 0.00 & 3332 & 391.60 \\
\hline & Norartocarpeti & 10 & -42.01 & -11.99 & 0.00 & 3354 & 408.00 \\
\hline & Paucine & 8 & -40.86 & -12.54 & 0.00 & 3842 & 445.00 \\
\hline & Procyanidin & 10 & -34.66 & -10.99 & 0.00 & 3344 & 418.30 \\
\hline & Quinine & 5 & -35.95 & -9.29 & 0.00 & 3500 & 446.10 \\
\hline & Reserpine & 1 & -15.80 & -0.73 & -0.49 & 2344 & 249.80 \\
\hline & Riboflavin & 2 & -29.09 & -7.90 & 0.00 & 3102 & 394.50 \\
\hline & Steppogenin & 2 & -25.94 & -7.87 & 0.00 & 2570 & 282.50 \\
\hline & Stigmasterol & 6 & -39.49 & -10.03 & 0.00 & 3600 & 486.80 \\
\hline & Triterpenoids & 2 & -27.55 & -8.23 & 0.00 & 2424 & 281.50 \\
\hline & Vanillin & 1 & -36.77 & -9.31 & 0.00 & 3982 & 507.00 \\
\hline & Yohimbine & 1 & -37.36 & -9.52 & 0.00 & 3730 & 461.70 \\
\hline $\begin{array}{l}\text { SARS-Cov-2 } \\
\text { main protease }\end{array}$ & $\begin{array}{ll}\text { Allyl } & \text { propyl } \\
\text { disulfide } & \end{array}$ & 6 & -25.75 & -6.58 & 0.00 & 2730 & 287.00 \\
\hline (6W63) & Apigenin & 1 & -39.74 & -12.31 & 0.00 & 3762 & 432.80 \\
\hline & Aristolochic acid & 7 & -53.99 & -17.66 & 0.00 & 5756 & 681.30 \\
\hline & Artocarpesin & 2 & -40.32 & -13.19 & 0.00 & 4290 & 494.50 \\
\hline & Ascorbic acid & 4 & -43.81 & -14.33 & 0.00 & 3994 & 458.10 \\
\hline & Asparagine & 8 & -25.54 & -8.54 & 0.00 & 2160 & 257.80 \\
\hline & Camphene & 1 & -28.39 & -8.67 & 0.00 & 3394 & 355.00 \\
\hline & Chavicine & 4 & -49.50 & -16.06 & 0.00 & 4000 & 476.00 \\
\hline & Chrysoeriol & 7 & -42.44 & -14.40 & 0.00 & 4738 & 553.70 \\
\hline & Cianidanol & 7 & -23.58 & -9.21 & 0.00 & 2514 & 275.20 \\
\hline & Citronellal & 9 & -47.72 & -15.46 & 0.00 & 4132 & 509.10 \\
\hline & Cleomiscosin B & 2 & -51.24 & -16.39 & 0.00 & 4826 & 553.70 \\
\hline & Coumadin & 2 & -51.96 & -16.85 & 0.00 & 4832 & 603.50 \\
\hline & Dihydromorin & 2 & -41.72 & -12.41 & 0.00 & 3602 & 417.00 \\
\hline & Flavylium & 3 & -44.52 & -13.92 & 0.00 & 4258 & 502.40 \\
\hline
\end{tabular}




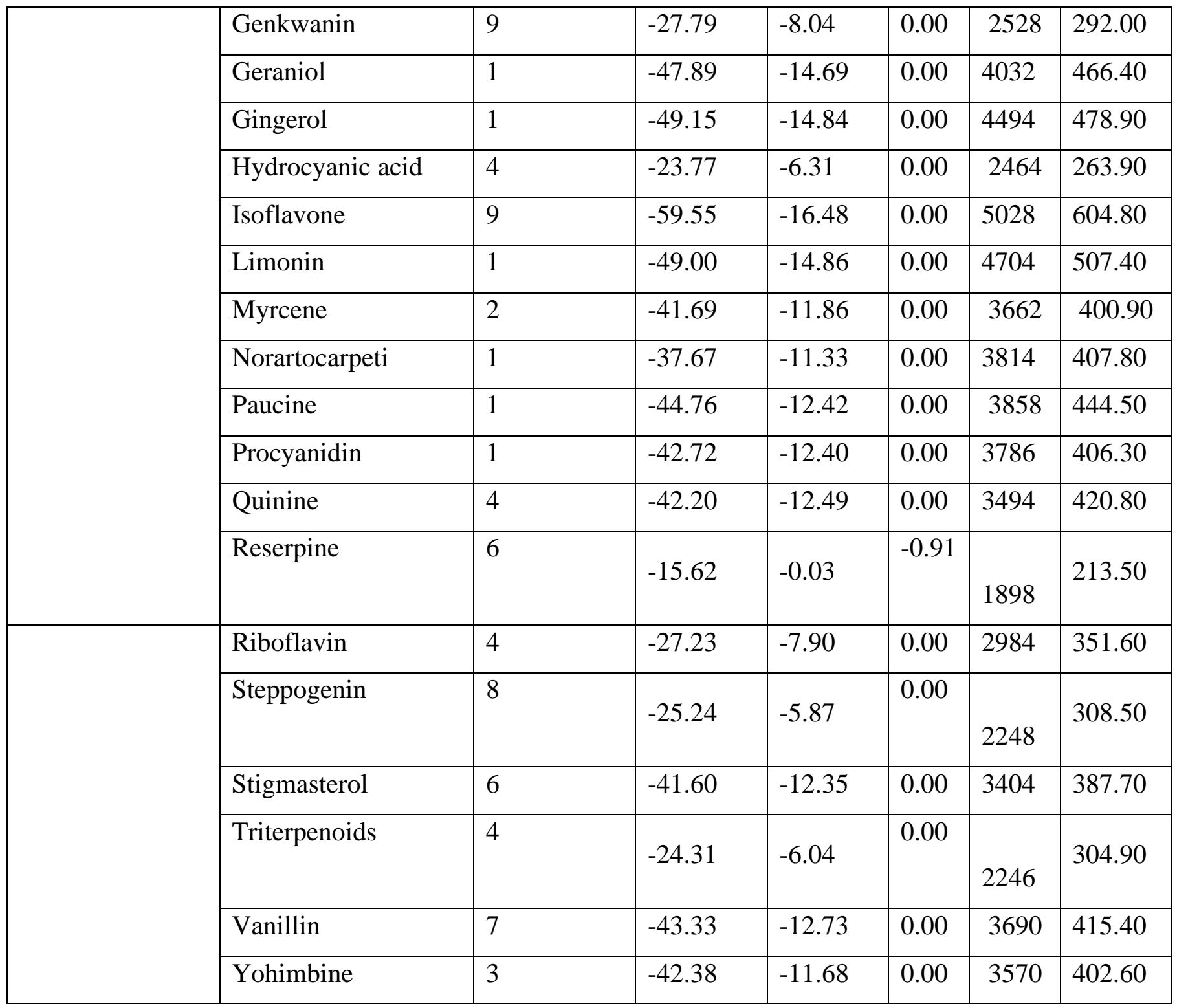

